\title{
CONVENTION ON INTERNATIONAL TRADE IN ENDANGERED SPECIES \\ OF WILD FAUNA AND FLORA
}

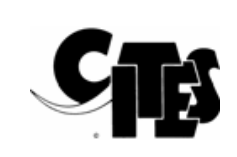

Fourteenth meeting of the Conference of the Parties

The Hague (Netherlands), 3-15 June 2007

\section{ADDITIONAL INFORMATION ON AMENDMENT PROPOSALS}

COP14 PROP. 9 TO COP14 PROP. 12

1. This document has been submitted by Algeria as additional information on amendment proposals CoP14 Prop. 9 to CoP14 Prop. 12 on Cervus elaphus barbarus, Gazella cuvieri, Gazella dorcas and Gazella leptoceros respectively.

2. The geographical designations employed in this document do not imply the expression of any opinion whatsoever on the part of the CITES Secretariat concerning the legal status of any country, territory, or area, or concerning the delimitation of its frontiers or boundaries. 


\section{Additional information on COP14 Prop. 9 for inclusion of Cervus elaphus barbarus (Barbary red deer) in Appendix I}

When considering the impact of international trade on Cervus elpahus barbarus, CITES Resolution Conf.9.24 (Rev.Cop13) should be applied : "When considering proposals to amend Appendix I or II, the Parties shall, by virtue of the precautionary approach and in case of uncertainty either as regards the status of a species or the impact of trade on the conservation of a species, act in the best interest of the conservation of the species concerned and adopt measures that are proportionate to the anticipated risks to the species."

\section{Biological Information (CITES Resolution Conf.9.24 (Rev.CoP13) Annex I)}

\section{International and national recognition of the precarious conservation status of the species}

Cervus elpahus barbarus is listed in Appendix I of the Convention on the Conservation of Migratory Species of Wild Animals (CMS) which includes "migratory species which are endangered" (CMS, Article III).

The species has the status of a "protected species" under Decree n'83-509 adopted on 08/20/1983 which regulates protected non-domestic animal species and under Article 54 of Algeria's national hunting legislation (Loi $n^{\circ}$ 04-07 adopted on 14 August 2004 on the regulation of hunting). Article 54 provides that:

"Animal species classified in the category of protected species are those known to be rare, endangered or the numbers of which have declined significantly"

Species recognized as protected species under Algeria's national hunting legislation may not be hunted, captured, traded or detained.

Furthermore and more recently, this species was granted, along with 22 other species, a specific and very strict protection status through the promulgation of Edict $n^{\circ} 06-05$ adopted on July 15, 2006 regulating the protection and the preservation of certain animal species threatened with extinction (www.SGG.dz Journal officiel $\left.n^{\circ} 47\right)$.

Available population data:

\begin{tabular}{|l|l|}
\hline Total Population Estimate & Source \\
\hline 800 in Tunisia & Ouami 2006; M. Hajji (in print) \\
\hline $50-60$ in Algeria & $\begin{array}{l}\text { Estimate made by the technical services } \\
\text { of the Forestry administration in Algeria in } \\
\text { the years 2004 to 2006 }\end{array}$ \\
\hline Extinct in Morocco & $\begin{array}{l}2006 \text { IUCN Red List of Threatened } \\
\text { Species; CITES Species Database 2007 }\end{array}$ \\
\hline
\end{tabular}

The total estimated population in Algeria is distributed as follows in the Northeastern region:

a. 43 individuals were counted in the wilaya of Guelma in 2004

b. 4 individuals on average were observed in the wilaya of Souk Ahras between 2004 and 2006

c. 7 individuals were observed in the wilaya d'El Tarf between 2004 and 2006

The table below lays out all direct observations of the Barbary red deer in the whole wilaya d'El Tarf from 2000 to April 2007. It indicates the rarity of this species which increases each year.

\begin{tabular}{|c|c|c|c|c|}
\hline Year & Stag (male) & doe & Fawn & $\begin{array}{c}\text { Troat (roar of } \\
\text { the rutting stag) }\end{array}$ \\
\hline 2000 & 03 & 13 & - & - \\
\hline 2001 & 03 & 03 & 01 & - \\
\hline 2002 & - & - & & - \\
\hline 2003 & - & 01 & - & - \\
\hline
\end{tabular}




\begin{tabular}{|c|c|c|c|c|}
\hline Year & Stag (male) & doe & Fawn & $\begin{array}{c}\text { Troat (roar of } \\
\text { the rutting stag) }\end{array}$ \\
\hline 2004 & - & - & - & 07 \\
\hline 2005 & - & - & - & - \\
\hline 2006 & 02 & 01 & - & - \\
\hline $\begin{array}{c}04 / 28-29 \text { and } \\
30 / 2007\end{array}$ & 02 & 02 & - & - \\
\hline
\end{tabular}

\section{Data on the decrease of habitat and population}

The most recent study has documented a considerable decrease in the range of Cervus elaphus barbarus and the small size of its population:

"The historical range of this deer covered large parts of Algeria, Tunisia and possibly Morocco, at present, the Barbary deer is restricted to a small area of cork oak and pine forest on the TunisianAlgerian border - a concentration that makes it particularly susceptible to diseases and forest fires that are not uncommon in the region (Kock \& Schomber, 1961; Cowan \& Holloway, 1973; Dolan, 1988; Oumani, 2006). (...)

A. Oumani (pers. comm., 2006) estimated the total population size of C. e. barbarus in Tunisia to be about 800 individuals. This is in clear contrast to the census results obtained by the DGF according to which there are 2000 deer in Tunisia (DGF, 1994; see also Dolan, 1988, who gives the same number). In addition to protection through government programmes, the WWF, in the context of the Regional Euro-Mediterranean Programme for the Environment (SMAP), is coordinating a project at El Feidja and Mhebe's including studies on the population size and ecology of the deer in north-western Tunisia and the establishment of a deer enclosure at Mhebe`s.

In Algeria, the stock of the Barbary deer is estimated to have been about 300-400 heads in the early 1950s before the Algerian war for independence and 400-600 in the mid-1970s (Salez, 1959; Kock \& Schomber, 1961; Wemmer,1998; for an estimate on population density in Algeria cf. Burthey et al., 1992)." (M. Hajji in print)

References to forest fires as one of the main causes for the degradation of the species' habitat, and thus for the regression of its range in Algeria, are justified by the overview presented below which lists recorded forest fires from 2001 to 2006 in the wilayas which constitute the range of Cervus elaphus barbarus in Algeria.

Areas burned by forest fires (in hectares) for the period $2001-2006$

\begin{tabular}{|c|c|c|c|c|c|c|}
\hline Wilaya & $\mathbf{2 0 0 1}$ & $\mathbf{2 0 0 2}$ & $\mathbf{2 0 0 3}$ & $\mathbf{2 0 0 4}$ & $\mathbf{2 0 0 5}$ & $\mathbf{2 0 0 6}$ \\
\hline El Tarf & 57 & 1550 & 133 & 61 & 107 & 89 \\
\hline Guelma & 118 & 312 & 10 & 9 & 771 & 139 \\
\hline Souk- Ahras & 148 & 112 & 45 & 22 & 192 & 167 \\
\hline Total (Ha) & $\mathbf{3 2 2}$ & $\mathbf{1 9 7 4}$ & $\mathbf{1 8 8}$ & $\mathbf{9 2}$ & $\mathbf{1 0 7 1}$ & $\mathbf{3 9 5}$ \\
\hline
\end{tabular}

Note : natural regeneration of broad-leaf forest under good climatic conditions (productive forest) in the South of the Mediteranean basin usually takes between 15 and 20 years.

Experts also report acute enforcement problems which render national conservation efforts ineffective:

"The fact that neither of the two reserve populations (El Feidja and Mhebe's) has increased is explained by Oumani (2006) by the dispersal of the deer from the reserve areas into adjacent habitats. In addition, poaching is still an important factor in limiting population growth of the Barbary deer in Tunisia." (M. Hajji, in print)

With regard to hunting infractions in Algeria, the information provided by the national services of police shows that two infractions on the species were committed in 2002 in the wilayas of d'EITarf et de Souk Ahras. These led to the arrest of 3 persons. These hunting infractions were:

- Death or harm inflicted on a protected animal

- Hunting, destruction, capture and sale of a protected animal 
Furthermore, in 2004, Algerian press, in the Newspaper EL WATAN (edition from 12/11/2004), highlighted the problem of poaching that is affecting this species after interviewing populations in the species' range. The widely-read newspaper reported that:

"Citizens spoke with a lot of emotion about the killings of Barbary red deer by groups of poachers. A pregnant doe was killed, ripped open and its fawn thrown to jackals by poachers from the locality of d'El Frin. It was apparently not the only one, they knew of half a dozen specimens killed by a group of hunters who no longer hesitate penetrating the Tunisian territory to drive out the deer who found refuge in this area. The population, who numbered 300 specimens in the mid 1980s, has completely disappeared according to this press article, decimated by the combined effects of poaching and of the reduction of its range. Deer are off course killed for their meat and their trophy, but also because one wishes to abandon himself to the pleasure of tracking"

The species consequently meets the following biological criteria for a listing in CITES Appendix I:

- CITES Resolution 9.24 (Rev. CoP13), Annex I criteria A i), ii), iv) and v) : the wild population is small and is characterized by "an observed, inferred or projected decline in the number of individuals or the area and quality of habitat"; each subpopulation is "very small"; the wild population encounters "large short-term fluctuations in population size" and a "high vulnerability to either intrinsic or extrinsic factors";

- CITES Resolution 9.24 (Rev. CoP13), Annex I criteria B i), ii), iii), and iv): The wild population has a restricted area of distribution and is characterized by "fragmentation or occurrence at very few locations "a high vulnerability to either intrinsic or extrinsic factors" and "an observed, inferred or projected decrease in (...) the area of distribution, the area of habitat, the number of individuals and the quality of habitat"

- CITES Resolution 9.24(Rev. CoP13), Annex I Criteria C i) and ii): there is "A marked decline in the population size in the wild, which has been (...)observed as ongoing (...) inferred or projected on the basis of (...) a decrease in area of habitat; a decrease in quality of habitat; levels or patterns of exploitation; a high vulnerability to either intrinsic or extrinsic factors;"

\section{Trade information}

CITES Article II, and RC 9.24 (Rev. CoP13), state that Appendix I shall include all species threatened with extinction which are or may be affected by trade.

RC 9.24 (Rev. CoP13) specifies in Annex 5 that a species "is or may be affected by trade" if:

1) "it is known to be in trade (using the definition of 'trade' in Article I of the Convention), and that trade has or may have a detrimental impact on the status of the species; or"

2) "it is suspected to be in trade, or there is demonstrable potential international demand for the species, that may be detrimental to its survival in the wild."

Analysis of the UNEP-WCMC CITES Trade Database shows the following trade data for subspecies of Cervus elaphus from 2000 to 2005 (Range States are marked with a *):

\begin{tabular}{|c|c|}
\hline Species & Reported Trade for 2000- 2006 \\
\hline Cervus elaphus barbarus (Barbary Red deer) & 8 (live) \\
\hline Purpose & Reintroduction into the Wild \\
\hline Origin & Wild \\
\hline Country of Export & Tunisia* \\
\hline Country of Import & Algeria* $^{*}$ \\
\hline Cervus elaphus hanglu (Kashmir deer) & 3 (1 horns; 1 bones; 1 carvings) \\
\hline Cervus elaphus bactrianus (Bactrian deer) & $\begin{array}{l}78 \text { (43 leather products; } 22 \text { garments; } 9 \\
\text { live; } 3 \text { trophies; } 1 \text { carvings) }\end{array}$ \\
\hline
\end{tabular}

Hunting is a major threat to the species. The fact that hunting occurs in violation of national conservation laws implies that the impact of illegal trade on the species is almost impossible to evaluate. The existence of 
illegal hunting for this species and the fact that hunting prohibitions are not respected could indicate that a thriving international black market is in place involving illegally hunted Cervus elaphus barbarus.

Despite the lack of documented trade in Cervus elaphus barbarus, the species remains threatened by the existence of an important market for parts and products of Cervus elaphus which locally drives illegal hunting of the species.

The existence of a market for Cervus elaphus parts and products is well recognized internationally:

"Deer [Cervus elaphus] have been used to stock game parks for recreational and trophy hunting. Deer have been farmed for venison, velvet and skins/hides, as well as for Asian medicines using antlers, velvet, tails and testicles, and teeth for jewellery (Auckland Regional Council- PestFacts)." (Global Invasive Species Database accessed in April 2007)

"Markets for velvet antler are not always readily available in the United States, but large ethnic Asian populations in some major North American cities (San Francisco, Vancouver) do use traditional medicines and tonics. Establishing markets in these metropolitan areas may be possible. It is also possible to export antlers to Asia. However, the product will compete with the large volumes of velvet antler produced in New Zealand, Russia and China.

Deer hides are a potentially valuable by-product from slaughtered deer. In New Zealand virtually all hides are used in suede leather production and will return to the farmer between $\$ 10$ and \$20. Deer suede is used in fine garment manufacture, as it is fully washable.

Red deer tails contain a deposit of brown fatty tissue that serves as a scent gland. Red deer tails are dried and marketed in Asia for use in herbal medicines and tonics. Returns to the farmer range between $\$ 2.50$ to $\$ 10$ per tail. Fallow deer tails do not contain this gland and have no commercial value.

It is difficult to establish markets for eye teeth, pizzles, and offal, due to the limited numbers of deer slaughtered." (Golz 1993)

"The main products produced from deer [Cervus elaphus and Dama dama] are venison and velvet antler. The major consumer of venison in the world is Germany with 40-50,000 tonnes of venison consumed annually. The other major markets for venison are in Asia, while domestic sales are increasing in Australia and New Zealand. Deer are the only species which produce velvet antler. The estimated production of green velvet antler will be approximately 3,000 metric tonnes as the world population of farmed deer approaches five million (Hudson, 1999; Mackay, 1998). Good quality mature red stags can yield $3 \mathrm{~kg}$ or more of antler and up to $1 \mathrm{~kg}$ per year for fallow (Tuckwell, 1998). Venison animals are slaughtered at 12 to 24 months of age with carcase weights ranging from 22-32 kg for fallow, up to 48-65 kg for red deer and higher for wapiti hybrids." (ANZCCART accessed in April 2007)

Medicinal properties of red deer velvet antlers have been listed in various studies (Tuckwell 2003).

Traditional Chinese medicine indicates the use of deer velvet for systematic exhaustion, depression, cold, lower back pain, weak pulse, impotence, spermatorrhea, low white cell counts, regulation of the adrenal cortex, regulation of the energy metabolism, promotion of sexual function, growth promotion, and strengthening of resistance (Tuckwell 2003).

Purported health benefits from the use of deer antler velvet also are broadly advertised in Western markets. An advertisement in Canada mentions for example, that velvet antler from the red deer:

- "significantly" increases red blood cell count and enhances the function of the entire immune system;

- facilitates better circulation, heightens oxygen and essential amino acids levels, and reduces the level of free radicals;

- helps in reaching and maintaining "optimum physical shape";

- prevents premature aging; allows regeneration of fiber, cartilage, bone and cells;

- prevents bone decalcification; reduces cramps and premenstrual symptoms in women, while it bolsters the hormonal system and eases the menopausal transition;

- has aphrodisiac properties for men and is valuable in the relief of impotence, as well as the negatives effects of andropause;

- etc. 
Note: The product advertised is called Velnor Velvet Antler; other potential benefits are listed at <http://www.velnor.com/Benefits1.pdf> Price for this product is advertised at US $\$ 48.69$ for 100 capsules (http://www.maisonradical.ca/Velnor/Bois_de_Velours.htm). Similar products cost about the same price and advertise the same type of health benefits (see for example the product Cervifor advertised at $<$ http://www.nutrivea.com/cervifor.htm> for US \$ 52.95 for 60 capsules)

Research indicates that Asiatic markets (mainly Korea) "prefer red deer and Wapiti velvet antlers over the fallow deer products. In 1989 returns for red deer velvet antlers ranged from $\$ 75$ to $\$ 125$ per pound, and for fallow antlers ranged from $\$ 30$ to $\$ 45$ per pound." (Golz 1993)

In 2000-2001 the price of venison varied from $\$ 3.80$ to $\$ 5.00$ per $\mathrm{kg}$ (State of Victoria, Department of Primary Industries, 2002). Velvet prices are known to be "very volatile, depending on export demand but specialist velvet stags (Reds and Elk) may produce velvet worth hundreds of dollars" (State of Victoria, Department of Primary Industries, 2002).

An Appendix I listing of the species would encourage greater cooperation among Range States of the species, greater control of illegal trade and better implementation of protective national laws of range States by potential consumer countries of parts and products.

\section{Information on the consultation of Range States}

Other range States for Cervus elaphus barbarus are Tunisia and probably Morocco.

Consultations with representatives from other range States, in particular during a regional meeting in March 2007, were able to confirm the significant regression of this species and the degradation of its habitat. This species is thus confronted by high risk of trade, in particular for meat, products, trophies and decoration.

\section{References}

- Deer Specialist Group 1996. Cervus elaphus ssp. barbarus. In: IUCN 2006. 2006 IUCN Red List of Threatened Species. <www.iucnredlist.org>. Downloaded on 30 April 2007.

- Global Invasive Species Database, Invasive Species Specialist Group (ISSG) of the IUCN Species Survival Commission, (http://www.issg.org/database) [last accessed in April 2007]

- G. M. Hajji, F. E. Zachos, F. Charfi-Cheikrouha, G. B. Hartl (2007), "Conservation genetics of the imperilled Barbary red deer in Tunisia", Animal Conservation 10 (2), 229-235. (in print)

- DH Nussey, J Pemberton, A Donald and LEB Kruuk, "Genetic consequences of human management in an introduced island population of red deer (Cervus elaphus)", Heredity (2006) 97, 56-65 available at <http://www.zoo.cam.ac.uk/zoostaff/larg/pages/DanPDF06Heredity.pdf>

- Christian Pitraa, Joerns Fickela, Erik Meijaardb, P. Colin Grovesc, "Evolution and phylogeny of old world deer", received 6 May 2004; revised 14 July 2004, available online at $<$ http://arts.anu.edu.au/grovco/Pitra\%20deer.pdf>

- Chris Tuckwell (2003), "Velvet Antler a summary of the literature on health benefits", A report for the Rural Industries Research and Development Corporation, Australian government available at < http://www.rirdc.gov.au/reports/DEE/03-084.pdf>

- Theresa Golz, "Red and Fallow Deer", Alternative Agriculture Series, Number 9, North Dakota State University, January 1993, available online at <http://www.ag.ndsu.edu/pubs/alt-ag/deer.htm>

- Z.H. Miao, P.C. Glatz, A. English and Y.J. Ru, "Managing fallow deer (Dama dama) and red deer (Cervus elaphus) for animal house research", Australian and New Zealand Council for the Care of Animals in Research and Teaching Ltd (ANZCCART) available online at <http://www.adelaide.edu.au/ANZCCART/publications/Deer_Facts_Sheet.pdf> 
- State of Victoria, Department of Primary Industries, "Deer - Farm Diversification Information Service, Bendigo" Agriculture Notes, September 2002, AG0649, ISSN 1329-8062 available online at <http://www.dpi.vic.gov.au/dpi/nreninf.nsf/9e58661e880ba9e44a256c640023eb2e/b54c2103c419f50cca2 56f100021bc0c/\$FILE/AG0649.pdf> 


\section{Additional information on COP14 Prop. 10 for inclusion of Gazella cuvieri (Cuvier's gazelle) in Appendix I}

Gazella cuvieri is highly endangered in all range States (Algeria, Tunisia and Morocco). The precarious conservation status of Cuvier's gazelles is due to a combination of threats (poaching, illegal hunting, habitat loss and degradation). The threat of illegal trade adds to the pressure on wild populations. When considering the impact of international trade on Gazella cuvieri, CITES Resolution Conf.9.24 (Rev.Cop13) should be applied : "When considering proposals to amend Appendix I or II, the Parties shall, by virtue of the precautionary approach and in case of uncertainty either as regards the status of a species or the impact of trade on the conservation of a species, act in the best interest of the conservation of the species concerned and adopt measures that are proportionate to the anticipated risks to the species."

\section{Biological Information (CITES Resolution Conf.9.24 (Rev.CoP13) Annex I)}

\section{International and national recognition of the precarious conservation status of the species}

Gazella cuvieri is listed as Endangered by the International Union for the Conservation of Nature (IUCN Red List 2006).

The species is listed in Appendix I of the Convention on the Conservation of Migratory Species of Wild Animals (CMS) which includes "migratory species which are endangered" (CMS, Article III).

The species is in Class A of the 1968 African Convention on the Conservation of Nature and Natural Resources which provides that "the hunting, killing, capture or collection of specimens shall be permitted only on the authorization in each case of the highest competent authority and only if required in the national interest or for scientific purposes."

A 2006 assessment of the conservation status of the species shows that it is endangered in Morocco, Tunisia and Algeria, all range States of the species (CMS 2006 reproduced in Annex I of this document).

Available population data:

\begin{tabular}{|l|l|l|}
\hline Range State & Population Estimate & Source \\
\hline Morocco & $600-1500$ & CMS 2006 \\
\hline Algeria & 500 & $2005 / 2006$ national survey \\
\hline Tunisia & $300-400$ & CMS 2006 \\
\hline Total & $1400-2400$ & \\
\hline
\end{tabular}

Data on the decrease of habitat and population

Algeria reported at CITES CoP14 Prop.10 that Gazella cuvieri was threatened by both habitat destruction and degradation which is a problem shared by other range States. The decrease of habitat and distribution for Cuvier's gazelles is well recognized internationally.

Most recently, experts on the Sahelo-Saharian antelopes have shown that populations of the species are highly fragmented and that its habitat is in decline:

"If until the recent past, the general distribution of Cuvier's gazelle had not changed much in relation to its historical range, the species is now in sharp geographical decline in Morocco. In most of its range (Eastern Morocco, High, Middle and Saharan Atlas), populations seem to be highly fragmented. Recent discoveries, confirming older data, made it possible to localise substantial populations in Western Anti Atlas and further in the South, in North-western Sahara, with an extension of known range towards the south between the lower Drâa and the Aydar massif (Aulagnier et al., 2001; Cuzin, 1996, 2003)." (CMS 2006; emphasis added) 
"The degradation and decline of habitats [for Cuvier's Gazelle] is mainly due to the continuous expansion of pastureland for livestock and the deforestation for agriculture or charcoal. As a consequence, the numbers have been severely reduced and the range fragmented." (CMS 2006)

The intensity of the exploitation for Gazella cuvieri conflicts with the low reproduction rate of the species which only produces one litter of one offspring per year in April or May (CMS 2006)

Experts report that Gazella cuvieri is less tolerant of disturbance than other gazelle species such as Gazella dorcas (CMS 2006).

The species consequently meets the following biological criteria for a listing in CITES Appendix I:

- CITES Resolution 9.24 (Rev. CoP13), Annex I criteria A i), ii) and v) : the wild population is small and is characterized by "an observed, inferred or projected decline in the number of individuals or the area and quality of habitat"; the wild population encounters a "high vulnerability to either intrinsic or extrinsic factors";

- CITES Resolution 9.24 (Rev. CoP13), Annex I criteria B i), ii), iii), and iv): The wild population has a restricted area of distribution and is characterized by "fragmentation or occurrence at very few locations"; "large fluctuations in the area of distribution or the number of subpopulations", "a high vulnerability to either intrinsic or extrinsic factors" and "an observed, inferred or projected decrease in (...) the area of distribution, the area of habitat, the number of individuals and the quality of habitat"

- CITES Resolution 9.24(Rev. CoP13), Annex I Criteria C i) and ii): there is "A marked decline in the population size in the wild, which has been (...)observed as ongoing (...) inferred or projected on the basis of (...) a decrease in area of habitat; a decrease in quality of habitat; levels or patterns of exploitation; a high vulnerability to either intrinsic or extrinsic factors;"

\section{Trade information}

CITES Article II, and RC 9.24 (Rev. CoP13), state that Appendix I shall include all species threatened with extinction which are or may be affected by trade.

RC 9.24 (Rev. CoP13) specifies in Annex 5 that a species "is or may be affected by trade" if:

1) "it is known to be in trade (using the definition of 'trade' in Article I of the Convention), and that trade has or may have a detrimental impact on the status of the species; or"

2) "it is suspected to be in trade, or there is demonstrable potential international demand for the species, that may be detrimental to its survival in the wild."

Analysis of the UNEP-WCMC CITES Trade Database shows that from 2000 to 2005, 24 live specimens were traded between United Arab Emirates (country of import) and Canada (country of export). Fourteen were traded for breeding in captivity and 10 for reintroduction or introduction into the wild.

Experts have shown that despite strong national protection, the species is subject to high levels of poaching and illegal hunting which greatly impact the remaining populations:

"Even though its preferred habitat ensures a better protection against hunters in vehicles than that of other species of North African gazelles (De Smet et al., in press), the species is still subject, at least locally, to high poaching pressure. Its populations have thus been reduced, in places, to a few dispersed groups." (CMS 2006 reproduced in Annex)

With regard to hunting infractions in Algeria, the information provided by the national services of police shows that seven infractions were found from 2003 to 2006 in the wilayas of Tissemsilt and Relizane. These led to the arrest of 18 persons. These hunting infractions were:

- Death or harm inflicted on a protected animal

- Hunting, destruction, capture and sale of a protected animal

The fact that take and hunting of the species occur in violation of national conservation laws implies that the impact of illegal trade on the species is almost impossible to evaluate. The existence of illegal hunting for this species and the fact that hunting prohibitions are not respected could indicate that a thriving international black market occurs in illegally hunted Cuvier's gazelles. 
An Appendix I listing of the species would encourage greater cooperation among Range States of the species, greater control of illegal trade and better implementation of protective national laws of range States by potential consumer countries of trophies and parts and products.

A 2006 report on wildlife trade in Somalia mentions that antelope meat is sold in local restaurants in the Middle East. This report also mentions that the United Arab Emirates are "one of the most important importing countries for antelopes" and that "the selling price for antelopes varies between 600 and 700 US\$, although the actual price is difficult to asses because intermediate brokers are involved in the wildlife business." (Amir 2006)

\section{Information on the consultation of Range States}

Other range States for Gazella cuvieri are Morocco and Tunisia.

Consultations with representatives from other range States, in particular during a regional meeting in March 2007, were able to confirm the significant regression of this species and the degradation of its habitat. This species is thus confronted to high risks of trade in particular for trophies and decoration.

\section{References}

- Antelope Specialist Group 1996. Gazella cuvieri. In: IUCN 2006. 2006 IUCN Red List of Threatened Species. <www.iucnredlist.org>. Downloaded on 16 March 2007.

- CMS Technical Series Publication $N^{\circ} 11$, Sahelo-Saharan Antelopes Status and Perspectives: Report on the conservation status of the six Sahelo-Saharan Antelopes, CMS SSA Concerted Action 2006 available online

- G. Amir, Wildlife Trade in Somalia, A report to the IUCN/SSC/Antelope Specialist Group - Northeast African Subgroup, 2006.

- CMS, Analysis of National Reports to the CMS 2005, Annex II: Appendix I Species, Prepared and produced by: UNEP World Conservation Monitoring Centre, Cambridge, UK on behalf of the Secretariat to the CMS available online.

- F. Cuzin, "Les Grands Mammifères du Maroc Méridonal (Haut Atlas, Anti Atlas et Sahara): Distribution, écologie et conservation", Phd research 2003.

- Second séminaire sur les antilopes Sahélo-Sahariennes, Rapports Nationaux, 2003 (includes information on Algeria, Burkina Faso, Ethiopia, Mali, Maroc, Mauritanie, Niger, Senegal, Sudan, Tchad, Tunisia)

- CMS, Synthesis of Party Reports, Part II: Information on Appendix I-listed Species, COP7 Conference Document: UNEP/CMS/Conf 7.6.1 Part II, Compiled by the UNEP - World Conservation Monitoring Centre under contract to the UNEP/CMS Secretariat September 2002 available online.

- Mallon \& Kingswood. 2001.In Mallon, D. P. and Kingswood, S. C. (compilers). Antelopes. Part 4: North Africa, the Middle East, and Asia. Global survey and regional Action Plans. SSC Antelope Specialist Group, IUCN, Gland, Switzerland and Cambridge, UK.

- $\quad$ East, R. (comp.) (1999). African Antelope Database 1998. Compiled by Rod East and the IUCN/SSC Antelope Specialist Group. Occasional paper of the IUCN Species Survival Commission No. 21. IUCN- The World Conservation Union 1999. 


\section{ANNEX I: Information on Cuvier's gazelle (Gazella cuvieri) provided by the Convention on Migratory Species}

\section{Population estimates and distribution}

Extract from CMS Technical Series Publication $N^{\circ} 11$, Sahelo-Saharan Antelopes Status and Perspectives: Report on the conservation status of the six Sahelo-Saharan Antelopes, CMS SSA Concerted Action 2006 available online.

\subsubsection{Decline of the range.}

In Morocco, the range of Gazella cuvieri, which covered the whole of the mountain chains and associated plateaux, diminished considerably during the 20th century: in the 1930's (or possibly later), it disappeared from the lower Seguia El Hamra, in the 1960's, from the region of Rabat and Casablanca, from several localities in the Middle Atlas at the same time (Cuzin, 1996).

In Algeria, it occupied the slopes of the Tellian chains, those of the more southern massif formed by the Saharan Atlas, and the massifs in the eastern part of the country (Tristam, 1860; Loche, 1867; Pease, 1896; Joleaud, 1929; Heim de Balsac, 1936). It disappeared from a large part of the Tellian Atlas to the east of Teniet el Had, but it was still noted in a few areas of the Mediterranean coast until about 1930 (Joleaud, 1926; Lavauden, 1929; Seurat, 1930).

In Tunisia, where it occupied the area from the Ridge to the region of Tunis, and the pre-Saharan massifs, it was still fairly abundant in 1936 in the entire Tunisian Ridge from the Algerian border to the Djebel Bou Kornine 17 kilometers south of Tunis (Kacem et al., 1994). The species no longer survived in the 1970's except in the vicinity of the Djebels Chambi and Khchem El Kelb between Kasserine and the Algerian border (Kacem et al., 1994); in Dghoumes National Park east of Tozeur, it survived until 1992 (A.Chetoui, head of nat.park, pers.comm.).

\subsubsection{Residual distribution.}

If until the recent past, the general distribution of Cuvier's gazelle had not changed much in relation to its historical range, the species is now in sharp geographical decline in Morocco. In most of its range (Eastern Morocco, High, Middle and Saharan Atlas), populations seem to be highly fragmented. Recent discoveries, confirming older data, made it possible to localise substantial populations in Western Anti Atlas and further in the South, in North-western Sahara, with an extension of known range towards the south between the lower Drâa and the Aydar massif (Aulagnier et al., 2001; Cuzin, 1996, 2003).

In Algeria, the range of distribution of Cuvier's gazelle is limited to the northern part of the country: it is not found anymore in the north of the Tellian Atlas. The species has only recently disappeared from a few localities and these are mainly in the north of its range of distribution. The populations of the western Tellian Atlas, Batna-Biskra, and the Aurès mountains are no longer contiguous, and some groups of the Saharan Atlas were recently eliminated (De Smet \& Mallon, 2001).

In Tunisia, after having reached very low numbers, the population currently seems to be increasing and is spreading out again (Kacem et al., 1994), essentially as a consequence of the efficient conservation measures implemented in and around Chambi National Park. For the Ridge in general, observations made in 1991 in the region of Siliana indicate that it is progressing towards the northeast, mainly from the principal population core in the surroundings of the Chambi National Park.

\subsubsection{Recolonisation prospects.}

This species is mobile and can rapidly recolonise sites occupied in the past insofar as passages remain possible, in particular if calm zones with waterholes exist between the sites. The Tunisian project of fixation of the species and natural recolonisation has had good results, and the Tunisian Government proposes continuing the implementation of a network of protected areas in which management measures similar to those applied in the Khchem el Kelb Reserve will be taken to encourage the redeployment of Cuvier's Gazelle along the full length of the Dorsale. In Morocco, the recent localisation of substantial populations in the south between the lower Drâa and the Aydar massif opens up new, interesting prospects for the conservation of the species. 


\subsection{Evaluation and evolution of populations.}

\section{Current numbers}

Estimated numbers : 1450-2450 (Morocco: 600-1500; Algeria: 560 ; Tunisia: 300-400).

In Morocco, the total population is currently estimated at between 600 and 1500 individuals including a population of several hundred individuals recently rediscovered in the lower Drâa (Aulagnier et al., 2001, Cuzin, 1996, 2003). The main populations are in the Western Anti Atlas (population increasing) and in the Lower Drâa-Aydar area (population decreasing), but small groups are spread on the Southern slopes of the High Atlas, in the Eastern High Atlas, in the Saharan Atlas, in the Central and Eastern Anti Atlas, and on the Southern slopes of Middle Atlas (Cuzin, 1996, 2003; Caron et al., 2004).

In Algeria, a study of the distribution and numbers of the species carried out at the end of the 1980's estimated the population at 445 individuals (Sellami et al., 1990); De Smet in 1987 estimated the population at minimum 400 individuals and perhaps 500 (De Smet, 1987); in 1991 his estimates were of 560 individuals of which 235 in the Tellian Atlas (sites 1 to 5 in the table below), 140 in the Saharan Atlas (sites 6 to 12, 14 and 15), 135 in the east (sites 16 to 19), and 50 in the central group of the Mergueb (site 13) (De Smet, 1991); the table summarizing the distribution and numbers of Gazella cuvieri is taken from De Smet (1991):

1 Sidi Bel Abbes-Tlemcen-Telagh

2 Saida

50 individuals

3 Mascara 20

4a Tjaret Frenda 20

$4 \mathrm{~b}$ Djebel Nador 100

5 Ouarsenis Mountain

30

6 El Bayad - Brezina

15

7 Aflou-Laghouat

10

8 Ain Sefra-El Abiod Sidi Cheik

10

9 Bechar-Taghit

10

10 Djebel Senalba (Djelfa)

11 Djebel Sahari Hunting Reserve 30

12 Guelt es Stel 20

13 Mergueb Nature Reserve 10

14 Bou Saada 50

15 Djebel Bou Kahil

16 South Aurès (including Beni Imloul and Barika)

17 East of Biskra

18 Némentcha Mounts

19 Forests of Tebessa

Total 560

In Tunisia, the number of Cuvier's gazelles is not known with precision; currently, the main population in the region of Chambi National Park is estimated at 300 individuals (Kacem et al., 1994), and the total population is at least a little higher. The species is found, in fact, in 13 hunting reserves and massifs, listed below (Kacem et al., 1994): 
1 Djebel Khchem el Kelb

$2 \mathrm{Dj}$. Serrraguia

3 Dj. Gaubeul

4 Dj. Tamesmida

5 Dj. Dernaia

6 Dj. Chambi

$7 \mathrm{Dj}$. Semmama

8 Dj. Seloum

9 Dj. Es Sif

$10 \mathrm{Dj}$. Hamra

$11 \mathrm{Dj}$. Bireno

12 Ain Bou Driss $1^{\text {st }}$ Series

13 Oum Djeddour
2900 ha (Faunal Reserves 300 ha)

3000

3000

5000

16000

10000 (National Parks 6723 ha)

12000

8000

10000

3500

3000

3000

3000

82400 ha

\section{Total}

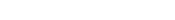

There is no precise figure on the former numbers of Cuvier's gazelle, but it was reputed to be common and locally abundant (e.a. Heim de Balsac, 1936). Harper (1945) cites Cabrera who mentioned it in 1932 as particularly numerous in the central part of the Middle Atlas, the territories of Beni Mguild and Ait Aiach, and the length of the contact line between this chain and the High Atlas. Also in 1932, Carpentier notes that it was formerly abundant in the Zaian district near Sidi Lamine and Khenifra (central Morocco).

\subsection{Migration.}

Joleaud (1929) mentions erratic movements and a somewhat nomadic life. On the Southern slopes of the High Atlas, animals are able to climb towards high altitude (up to 2.600m) in summer. In the High and Anti Atlas, gazelles were often present in pastures where cattle were not allowed; in the Souss plains, after the opening of a pasture to cattle, gazelles settled at a distance of $18 \mathrm{~km}$ (Cuzin 2003). In Northern Sahara, animals coming from the Aydar are moving in winter as far as the High Sequia El Hamra, where they are absent in summer (Cuzin 2003), and, in the Lower Drâa, animals are absent in dry pastures, and come back within a few weeks after a rainfall (Cuzin, pers. obs.).

\section{Conservation Status by Range State}

Extract from CMS Technical Series Publication N ${ }^{\circ} 11$, Sahelo-Saharan Antelopes Status and Perspectives: Report on the conservation status of the six Sahelo-Saharan Antelopes, CMS SSA Concerted Action 2006 available online.

\section{Morocco: Endangered}

The state of conservation of the species in Morocco was described recently by Cuzin (1996, 2003), on the basis of data found in Loggers et al. (1992), completed by new data gathered by the Water and Forest Service, by his personal observations, and by the observations of resident and visiting naturalists; it is primarily these recent data which are used here. The species is probably extinct in north-eastern Morocco since 1985. Its range has been greatly reduced in the Ida massif or Tanane, north of Agadir. The species was recently discovered on the southern gradient of the eastern Middle Atlas, towards Outat Oulad El Haj, as well as on hills of the High Plateaux, slightly more to the east (Cuzin, 1996, 2003; Caron et al., 2004). Some small groups have also been observed on the southern gradient of the central and eastern High Atlas, from the region of Ouarzazate to that of Rich, reaching an altitude of 2600 meters south of Imilchil, where the species is clearly transhumant: numerous testimonies indicate the presence of the species in summer, and its absence in winter (Cuzin, 1996, 2003). Outside of the Middle and Great Atlas, Cuvier's gazelle was recently observed at the western extremity of the Saharan Atlas in the region of Djebel Grouz (Caron et al., 2004).

Further towards the Sahara, recent discoveries indicate substantial populations in the western Anti Atlas and the northwestern Sahara, with an extension of known range towards the south between the lower Drâa and the Aydar massif (Cuzin, 1996, 2003). A group of three animals was observed south of Foum Zguid, in 1994. In 1995, the species was found in the entire region situated from the Drâa Wadi, at about a hundred 
kilometres upstream from its mouth, to the last relief north-east of Smara in the Aydar. This confirmed older data (Morales Agacino, 1949; Aulagnier \& Thévenot, 1986) and pushed the southern limit of known distribution southwards by about sixty kilometres (Cuzin, 1996).

\section{Algeria: Endangered}

The state of conservation of the species in Algeria was recently described by De Smet $(1989,1991)$ and De Smet et al., (in press), and it is mainly these recent data which are used here. In the northwest of the country, Cuvier's gazelle is much more widespread than what was thought. Almost all the large national forests of Aleppo Pines (Pinus halepensis) shelter small populations and there are contact zones between the majority of these populations. It is also relatively common in the hills between Mascara, Relzane, Tiaret, and Frenda, living there in open countryside with a mosaic of grain crops, vineyards, and pasture lands at the top of the hills. In the Saharan Atlas, most of the summits which are higher and less disturbed still harbour small groups of Cuvier's gazelle, the most substantial one of these being near Djelfa (Khirreddine, 1977). The most recent information indicates that some of these populations are growing. The most eastern populations are found in the Aurès, the Némentcha mounts, and the hills near the Tunisian border. Near Tebessa there is a concentration of Cuvier's Gazelles, which move to and from the Chambi National Park in Tunisia; further south, they also cross the border back and forth in the Tamerza region.

\section{Tunisia: Endangered}

In the 19th century, Cuvier's gazelle was present in all the Tunisian mountains, especially in the high chains of the Ridge in the region of Kasserine, in the northern chains of the Ridge near Ghardimaou, Tunis, and Zaghouan, and in the southern pre-Saharan chains around Gafsa and Tamerza. Its range of distribution had considerably decreased until the 1970's, before the Forest Office took energetic measures, and the numbers had fallen very low. Important measures of habitat management for Cuvier's Gazelle, combined with measures to protect the species, have recently enabled the Tunisian Forest Office to greatly improve the state of conservation of Cuvier's gazelle; the objectives of the Tunisian program aim to naturally recolonize the historical range of distribution. 


\section{Additional information on COP14 Prop. 11 for inclusion of Gazella dorcas (Dorcas gazelle) in Appendix I}

The precarious conservation status of Gazella dorcas (Dorcas gazelle) is due to a combination of threats (poaching, hunting, habitat loss and degradation). Present levels of trade add to the pressure on the population. When considering the impact of international trade on Gazella dorcas, CITES Resolution Conf.9.24 (Rev.Cop13) should be applied : "When considering proposals to amend Appendix I or II, the Parties shall, by virtue of the precautionary approach and in case of uncertainty either as regards the status of a species or the impact of trade on the conservation of a species, act in the best interest of the conservation of the species concerned and adopt measures that are proportionate to the anticipated risks to the species."

\section{Biological Information (CITES Resolution Conf.9.24 (Rev.CoP13) Annex I)}

\section{International and national recognition of the precarious conservation status of the species}

Gazella dorcas is listed as Vulnerable with decreasing populations by the International Union for the Conservation of Nature (IUCN Red List 2006).

The Northwest African populations of the species are also listed in Appendix I of the Convention on the Conservation of Migratory Species of Wild Animals (CMS) which includes "migratory species which are endangered" (CMS, Article III). A CMS report on the conservation status of Sahelo-Saharan Antelopes concluded that Dorcas gazelles have declined significantly in numbers: "Formerly common in its entire range, Gazella dorcas has entirely disappeared from many regions and been gravely reduced in numbers where it subsists." (CMS 2006 reproduced in Annex I of this document)

A 2006 assessment of the conservation status of the species shows that it is extinct in the wild in Senegal; probably extinct in Nigeria; endangered in Morocco, Libya and Mauritania; probably endangered in Mali, Burkina Faso; probably vulnerable or endangered in Chad and Niger; vulnerable in Tunisia and Egypt; probably near threatened or vulnerable in Sudan, and probably vulnerable in Algeria (CMS 2006 reproduced in Annex I of this document).

\section{Available population data:}

\begin{tabular}{|l|l|l|}
\hline Range State & Population Estimate & Source \\
\hline Chad & 3057 (declining) & CMS 2002 and CMS 2005 \\
\hline Mali & $2000-2500$ & CMS 2006 \\
\hline Egypt & $1000-2000$ (in rapid decline) & CMS 2006 \\
\hline Algeria & 619 & National Survey \\
\hline Morocco & $500-1500$ & CMS 2006 \\
\hline Niger & 100 & CMS 2006 \\
\hline Nigeria & Extinct & CITES Species Database \\
\hline Senegal & Extinct & CMS 2006 \\
\hline
\end{tabular}

Range States where no population data are available: Burkina Faso, Djibouti , Eritrea , Ethiopia , Jordan , Libyan Arab Jamahiriya, Mauritania, Somalia, Sudan, Togo, Tunisia, Yemen

\section{Data on the decrease of habitat and population}

Algeria reports in CITES CoP14 Prop.11 that Gazella dorcas is threatened by both habitat destruction and degradation; a problem which is shared by other range States. The decrease in range and habitat of Dorcas gazelles is well recognized internationally. Data provided by CMS and reproduced in the Annex of the 
present document show that there is a significant decline in the range of the species and that this decline affects all Northern African range States.

Most recently, experts on the Sahelo-Saharian antelopes have recognized that:

"The distribution of Gazella dorcas has been slowly declining, by fragmentation, in northern Africa since the late 1800s. By the mid-1900s, it had largely disappeared from the Atlas Mountains and Mediterranean coastal areas, but southward as far as the Sahel, it remained relatively well distributed. During the 1950s, 1960s, and 1970s, motorized hunting and, to a lesser extent, degradation and loss of habitat, severely impacted the species throughout its range, and although its overall distribution remained intact, its numbers had been greatly reduced (Dupuy, 1967), probably by half (Dragesco-Joffé, 1993), and it had been eliminated from large areas of its range, particularly those accessible to motorized vehicles. In the late 1980s, Gazella dorcas still occurred in all the Sahelo-Saharan Range States except Senegal, but its numbers had been substantially reduced, and it was considered threatened or endangered throughout the region with the exception of Niger and Chad, where relatively large populations occurred in the Airr-Ténéré and Wadi Rimé-Wadi Achim reserves, respectively (East ,1988, 1990, 1992)."

(CMS 2006 reproduced in Annex)

Experts also have reported that the species was "formerly common in its entire range" and has now "entirely disappeared from many regions and been gravely reduced in numbers where it subsists." (CMS 2006, ibidem)

The species consequently meets the following biological criteria for a listing in CITES Appendix I:

- CITES Resolution 9.24 (Rev. CoP13), Annex I criteria A i), and iv) : the wild population is small and is characterized by "an observed, inferred or projected decline in the number of individuals or the area and quality of habitat"; the wild population encounters "large short-term fluctuations in population size";

- CITES Resolution 9.24 (Rev. CoP13), Annex I criteria B i), ii), iii), and iv): The wild population has a restricted area of distribution and is characterized by "fragmentation", "Iarge fluctuations in the area of distribution or the number of subpopulations", "a high vulnerability to either intrinsic or extrinsic factors" and "an observed, inferred or projected decrease in (...) the area of distribution, the area of habitat, the number of individuals and the quality of habitat"

- CITES Resolution 9.24(Rev. CoP13), Annex I Criteria C ii): there is "A marked decline in the population size in the wild, which has been (...) inferred or projected on the basis of (...) a decrease in area of habitat; a decrease in quality of habitat; levels or patterns of exploitation; a high vulnerability to either intrinsic or extrinsic factors;"

\section{Trade information}

CITES Article II, and RC 9.24 (Rev. CoP13), state that Appendix I shall include all species threatened with extinction which are or may be affected by trade.

RC 9.24 (Rev. CoP13) specifies in Annex 5 that a species "is or may be affected by trade" if:

1) 'it is known to be in trade (using the definition of 'trade' in Article I of the Convention), and that trade has or may have a detrimental impact on the status of the species; or"

2) "it is suspected to be in trade, or there is demonstrable potential international demand for the species, that may be detrimental to its survival in the wild."

Analysis of the UNEP-WCMC CITES Trade Database shows that from 2000 to 2005, Dorcas gazelles have been heavily traded. This analysis also shows the existence of an international demand for the species with 13 CITES Parties involved in the export of the species and 22 CITES Parties involved its import. A drop in the total number of specimens traded occurred in 2005; this may indicate decreased availability (more than 300 specimens, parts or products were traded in 2000 and only 63 were traded in 2005). Most specimens in trade are live animals and trophies; most transactions are reported to be commercial trade.

Hunting is a major threat to the species and research shows that hunting is partially motivated by trade. A study led in 2003 on large mammals in Southern Morocco specifies for example that Gazella dorcas is highly sought by hunters and that hunting is in part performed by "hunters practicing in a commercial purpose, originating from the region or outside of the region, in order to sell the meat (the meat is considered as excellent, and, in the region of Tan Tan and Guelmim, it is discreetly sold for about $90 \mathrm{Dh}$ per $\mathrm{kg}$, which 
makes it the most expansive meat on the market), or trophies and animal parts to supply trade in 'attarin' and 'assabin' " . This study also specifies that hunters partially come from the Arabic Peninsula (Saudi Arabia and United Arab Emirates in particular) (Cuzin, 2003).

A 2006 report on wildlife trade in Somalia, a range State for Gazella dorcas, mentions that antelope meat is sold in local restaurants in the Middle East. This report also mentions that the United Arab Emirates are "one of the most important importing countries for antelopes" and that "the selling price for antelopes varies between 600 and 700 US\$, although the actual price is difficult to asses because intermediate brokers are involved in the wildlife business." (Amir 2006)

In Algeria, this species is, as is other gazelle species, hunted for hide and for trophies which can be highly sought after for both international and national trade, in particular under the form of mounted specimens.

Concerning hunting infractions in Algeria, the information provided by the national services of police shows that 5 infractions were found in 2004 and 2006 in the wilayas of d'El Bayadh and Laghouat. These led to the arrest of 20 persons. These hunting infractions were:

- Death or harm inflicted on a protected animal

- $\quad$ Hunting, destruction, capture and sale of a protected animal

A 2006 search on eBay showed trophies of Dorcas gazelles for sale:

- Dorcas gazelle horns mounted on a wall hanging were advertised for sale on eBay for Euros 38.50 on January 17, 2007

- A mounted Sudanese Dorcas gazelle skull was advertised for sale on eBay for Euros 53.71 at the same period

\section{Trade overview from 2000 to 2005 for Dorcas gazelles (Gazella dorcas):}

Source: UNEP-WCMC CITES Trade Database, 2006. (Highest and lowest trade data are marked with shaded cells)

\begin{tabular}{|l|c|c|c|c|c|c|r|r|}
\hline Term & $\mathbf{2 0 0 0}$ & $\mathbf{2 0 0 1}$ & $\mathbf{2 0 0 2}$ & $\mathbf{2 0 0 3}$ & $\mathbf{2 0 0 4}$ & $\mathbf{2 0 0 5}$ & Total & Wild (W) \\
\hline Live & $\mathbf{2 6 6}$ & $\mathbf{3 5 4}$ * & $\mathbf{3 4 9}$ & 354 & 290 & $\mathbf{6 2}$ & 1675 & 948 \\
\hline Trophies & $\mathbf{3 6}$ & $\mathbf{3 3}$ & $\mathbf{7}$ & 15 & 4 & $\mathbf{0}$ & 95 & $\mathbf{8 4}$ \\
\hline Bodies & 0 & 4 & 4 & 2 & 0 & 0 & 10 & 2 \\
\hline Specimens & 0 & 0 & 0 & 0 & 10 & 0 & 10 & 0 \\
\hline Bones & 0 & 0 & 0 & 6 & 0 & 0 & 6 & 6 \\
\hline Skulls & 0 & 2 & 2 & 0 & 0 & 0 & 4 & 4 \\
\hline Skins & 0 & 1 & 1 & 1 & 0 & 0 & 3 & 2 \\
\hline Skeleton & 0 & 0 & 0 & 0 & 1 & 1 & 2 & 0 \\
\hline Horns & 0 & 0 & 0 & 1 & 0 & 0 & 1 & 1 \\
\hline Total & $\mathbf{3 0 2}$ & $\mathbf{3 9 4}$ & $\mathbf{3 6 3}$ & $\mathbf{3 7 9}$ & $\mathbf{3 0 5}$ & $\mathbf{6 3}$ & $\mathbf{1 8 0 6}$ & $\mathbf{1 0 4 7}$ \\
\hline
\end{tabular}

* one time transaction of 294 wild specimen traded for commercial purposes.

\begin{tabular}{|l|l|l|l|l|l|l|l|}
\hline Total & $\begin{array}{l}\text { Commercial } \\
\text { Trade }\end{array}$ & Personal & $\begin{array}{l}\text { Hunting } \\
\text { Trophies }\end{array}$ & Scientific & Zoos & Breeding & $\begin{array}{l}\text { No purpose } \\
\text { reported }\end{array}$ \\
\hline 1806 & 1096 & 569 & 91 & 24 & 14 & 2 & 10 \\
\hline
\end{tabular}


Primary trading Parties from 2000 to 2005 for Dorcas gazelles (Gazella dorcas) (ranked in order of importance - range States of the species are marked with a (*)):

\begin{tabular}{|l|c|c|c|c|c|c|r|}
\hline \multicolumn{9}{|c|}{ Gross Export Trade Report, UNEP-WCMC CITES Trade Database, 2006. } \\
\hline Country of export. & $\mathbf{2 0 0 0}$ & $\mathbf{2 0 0 1}$ & $\mathbf{2 0 0 2}$ & $\mathbf{2 0 0 3}$ & $\mathbf{2 0 0 4}$ & $\mathbf{2 0 0 5}$ & \multicolumn{1}{c|}{ Total } \\
\hline Sudan* & 248 & 357 & 232 & 182 & 261 & 62 & 1342 \\
\hline South Africa & 0 & 0 & 0 & 125 & 0 & 0 & 125 \\
\hline Chad* $^{\star}$ & 9 & 18 & 6 & 22 & 1 & 0 & 56 \\
\hline United Arab Emirates & 0 & 0 & 20 & 0 & 1 & 1 & 22 \\
\hline Niger* & 0 & 2 & 3 & 17 & 0 & 0 & 22 \\
\hline Qatar & 0 & 0 & 0 & 0 & 17 & 0 & 17 \\
\hline Morocco* & 5 & 0 & 6 & 3 & 0 & 0 & 14 \\
\hline Algeria* & 0 & 4 & 4 & 1 & 0 & 0 & 9 \\
\hline Switzerland & 6 & 0 & 0 & 0 & 0 & 0 & 6 \\
\hline France & 5 & 0 & 0 & 0 & 1 & 0 & 6 \\
\hline Bahrain & 0 & 0 & 0 & 5 & 0 & 0 & 5 \\
\hline Egypt* & 0 & 0 & 0 & 5 & 0 & 0 & 5 \\
\hline Saudi Arabia & 0 & 0 & 1 & 0 & 0 & 0 & 1 \\
\hline
\end{tabular}

\begin{tabular}{|l|c|c|c|c|c|c|r|}
\hline \multicolumn{6}{|c|}{ Gross Import Trade Report, UNEP-WCMC CITES Trade Database, 2006. } \\
\hline Country of import. & $\mathbf{2 0 0 0}$ & $\mathbf{2 0 0 1}$ & $\mathbf{2 0 0 2}$ & $\mathbf{2 0 0 3}$ & $\mathbf{2 0 0 4}$ & $\mathbf{2 0 0 5}$ & Total \\
\hline United Arab Emirates & 94 & 322 & 28 & 150 & 179 & 38 & 811 \\
\hline Saudi Arabia & 69 & 16 & 47 & 139 & 49 & 0 & 320 \\
\hline Qatar & 28 & 2 & 155 & 26 & 22 & 24 & 257 \\
\hline Kuwait & 10 & 6 & 20 & 17 & 24 & 0 & 77 \\
\hline United States & 22 & 18 & 1 & 5 & 2 & 0 & 48 \\
\hline Syrian Arab Republic & 16 & 4 & 2 & 2 & 2 & 0 & 26 \\
\hline France & 6 & 0 & 0 & 10 & 0 & 0 & 16 \\
\hline Spain & 2 & 4 & 4 & 1 & 0 & 0 & 11 \\
\hline Bahrain & 5 & 0 & 6 & 0 & 0 & 0 & 11 \\
\hline Libyan Arab Jamahiriya* & 2 & 4 & 0 & 2 & 0 & 0 & 8 \\
\hline Germany & 0 & 5 & 0 & 0 & 1 & 1 & 7 \\
\hline Denmark & 4 & 0 & 3 & 0 & 0 & 0 & 7 \\
\hline Lebanon & 3 & 0 & 0 & 0 & 2 & 0 & 5 \\
\hline Canada & 0 & 0 & 4 & 0 & 0 & 0 & 4 \\
\hline Cameroon & 0 & 0 & 0 & 4 & 0 & 0 & 4 \\
\hline Egypt* & 4 & 0 & 0 & 0 & 0 & 0 & 4 \\
\hline Jordan* & 4 & 0 & 0 & 0 & 0 & 0 & 4 \\
\hline Yemen* & 2 & 0 & 2 & 0 & 0 & 0 & 4 \\
\hline Algeria* & 0 & 0 & 0 & 2 & 0 & 0 & 2 \\
\hline Switzerland & 2 & 0 & 0 & 0 & 0 & 0 & 2 \\
\hline Malta & 0 & 0 & 0 & 1 & 0 & 0 & 1 \\
\hline South Africa & 0 & 0 & 0 & 1 & 0 & 0 & 1 \\
\hline
\end{tabular}




\section{Information on the consultation of Range States}

Other range States for Gazella dorcas include: Burkina Faso , Chad, Djibouti , Egypt , Eritrea , Ethiopia , Jordan, Libyan Arab Jamahiriya, Mali , Mauritania, Morocco, Niger, Nigeria (extinct), Senegal (extinct), Somalia, Sudan, Togo, Tunisia, Yemen (IUCN 2000) Consultations with representatives from other range States, and in particular with Arabic countries during a regional meeting in March 2007, were able to confirm the significant regression of this species and the degradation of its habitat. This species is thus confronted to high risks of trade in particular for trophies and decoration.

\section{References}

- Mallon, D. \& Kingswood, S. 2000. Gazella dorcas. In: IUCN 2006. 2006 IUCN Red List of Threatened Species. <www.iucnredlist.org>. Downloaded on 6 April 2007.

- CMS Technical Series Publication $N^{\circ} 11$, Sahelo-Saharan Antelopes Status and Perspectives: Report on the conservation status of the six Sahelo-Saharan Antelopes, CMS SSA Concerted Action 2006 available online

- G. Amir, Wildlife Trade in Somalia, A report to the IUCN/SSC/Antelope Specialist Group - Northeast African Subgroup, 2006.

- CMS, Analysis of National Reports to the CMS 2005, Annex II: Appendix I Species, Prepared and produced by: UNEP World Conservation Monitoring Centre, Cambridge, UK on behalf of the Secretariat to the CMS available online.

- F. Cuzin, "Les Grands Mammifères du Maroc Méridonal (Haut Atlas, Anti Atlas et Sahara): Distribution, écologie et conservation", Phd research 2003.

- Second séminaire sur les antilopes Sahélo-Sahariennes, Rapports Nationaux, 2003 (includes information on Algeria, Burkina Faso, Ethiopia, Mali, Maroc, Mauritanie, Niger, Senegal, Sudan, Tchad, Tunisia)

- Ali and Zeleke, The status of Dorcas Gazelle in Ethiopia, Paper presented in the second workshop on the conservation and restoration of Sahelo-Saharan Antelopes, 1-5 May 2003 available at $<$ http://www.kbinirsnb.be/cb/antelopes/National\%20Reports/report\%20ethiopia.pdf >

- CMS, Synthesis of Party Reports, Part II: Information on Appendix I-listed Species, COP7 Conference Document: UNEP/CMS/Conf 7.6.1 Part II, Compiled by the UNEP - World Conservation Monitoring Centre under contract to the UNEP/CMS Secretariat September 2002 available online. 


\section{ANNEX I: Information on Dorcas gazelles (Gazella Dorcas) provided by the Convention on Migratory Species}

\section{Population estimates and distribution}

Extract from CMS Technical Series Publication N ${ }^{\circ} 11$, Sahelo-Saharan Antelopes Status and Perspectives: Report on the conservation status of the six Sahelo-Saharan Antelopes, CMS SSA Concerted Action 2006 available online.

\subsubsection{Decline of the range.}

The distribution of Gazella dorcas has been slowly declining, by fragmentation, in northern Africa since the late 1800s. By the mid-1900s, it had largely disappeared from the Atlas Mountains and Mediterranean coastal areas, but southward as far as the Sahel, it remained relatively well distributed. During the 1950s, 1960s, and 1970s, motorized hunting and, to a lesser extent, degradation and loss of habitat, severely impacted the species throughout its range, and although its overall distribution remained intact, its numbers had been greatly reduced (Dupuy, 1967), probably by half (Dragesco-Joffé, 1993), and it had been eliminated from large areas of its range, particularly those accessible to motorized vehicles. In the late 1980s, Gazella dorcas still occurred in all the Sahelo-Saharan Range States except Senegal, but its numbers had been substantially reduced, and it was considered threatened or endangered throughout the region with the exception of Niger and Chad, where relatively large populations occurred in the Airr-Ténéré and Wadi Rimé-Wadi Achim reserves, respectively (East ,1988, 1990, 1992).

\subsubsection{Residential Distribution.}

The most recent information is that Dorcas Gazelles still naturally occurs in all the Range States, except Senegal; however, with the exception of Algeria and Mali, where the distribution and abundance of gazelles may be increasing due to civil war (K. De Smet, pers. comm., January 1997; East, 1997), and Ethiopia, where several hundred occur in protected areas, Gazella dorcas continues to be threatened by illegal hunting and, to a lesser extent, loss of habitat due to livestock overgrazing, and its numbers are declining. About a hundred reportedly still occur in the Aïr-Ténéré National Nature Reserve in Niger (Poilecot, 1996). In Morocco, numbers are estimated at 500-1500; about half of which occur in protected areas; an important population of possibly several hundred animals occurs in the Adrar Soutouf in southern Western Sahara (F. Cuzin, comm. pers., May 2003). According to recent surveys, a population of 1000-2000 is in rapid decline in Egypt (Saleh, in press). Numbers in Mali are estimated at 2000-2500 (East, 1997), the area with the highest density is the North Tamesna (Lamarque, comm. pers. 2005). It still occurs in the Wadi Rimé-Wadi Achim reserve, but numbers are much reduced (East, 1996a). There are no recent estimates of total numbers of Gazella dorcas in Mauritania (B. Lamarche, in litt., October 1996; O. Hamerlynck, in litt., July 1996) or Tunisia (K.De Smet, pers. comm., January 1997). Its status is not known in Burkina Faso or Nigeria. The species qualify for vulnerable status (Hilton-Taylor 2002).

A comparison of dorcas encounter rates, based on the number of $\mathrm{G}$. dorcas seen per $\mathrm{km}$ during all recent surveys, since 2001, was done by Tim Wacher. It shows that the highest densities are found in Ouadi RiméOuadi Achim, Manga and Termit.

\subsection{Evolution and estimation of populations.}

Formerly common in its entire range, Gazella dorcas has entirely disappeared from many regions and been gravely reduced in numbers where it subsists.

\section{Conservation Status by Range State}

Extract from CMS Technical Series Publication № 11, Sahelo-Saharan Antelopes Status and Perspectives: Report on the conservation status of the six Sahelo-Saharan Antelopes, CMS SSA Concerted Action 2006 available online.

\section{Morocco: Endangered (Cuzin, 1996 and 2003).}

With the possible exception of the high elevation of the Atlas Mountains, the Dorcas gazelle was historically distributed throughout Morocco and Western Sahara (Aulagnier, 1992). In the 1800s, it reportedly occurred west of the Atlas Mountains at low densities and remained uniformly distributed and abundant elsewhere. By the 1950s, the species had disappeared west of the Atlas, except for one population in the vicinity of Safi, and had been reduced to low numbers on the northern, eastern and southern flanks of the Atlas; at the time, it also had become rare along the coast in the Western Sahara nearly to Dakhla (Aulagnier, 1992). In the early 1990s, the extent of the species' range had not changed, but it had been reduced to small widely 
dispersed groups east and south of the Atlas and throughout the Western Sahara (Aulagnier, 1992; Loggers et al., 1992). Nowadays, the only remaining population in the North-West of the Atlas chains is the small population of the M'Sabih Talaa Reserve, near Chichaoua. The species disappeared from the Souss plains in 1987, from the Noun region in 1996, and the only remaining individuals in the plains between Ouarzazate and Tafilalelt survive in the enclosures of the El Kheng Reserve. Elsewhere, the distribution of the species remains the same, but groups have been reduced to small sizes, continuously decreasing in numbers, dispersed to the East and South of the Atlas and throughout Western Sahara (Aulagnier, 1992, Loggers et al. 1992, Cuzin 2003) : in the Bas Draa, numbers went from 150 individuals in 1997 (Cuzin 1998) to around fourty individuals (F. Cuzin, comm. pers., 2003). It was recently estimated that a population of approximately 100-200 animals occurs west of the Atlas in the M'Sabih Talaa Reserve, near Chichaoua (Marraha 1996). East of the Atlas it is very rare, typically occurring in widely dispersed populations of 20-50 animals. A population of about 100 occurs at the base of Jebel Gouz and west to Figuig along the Algerian border. Approximately 50 are found in the upper Draa Valley in the vicinity of Zagora; 100-200 remain in the Middle Draa, primarily in the Tata Province, and about 200 occur in the Lower Draa between Assa and Msseyed ( $F$. Cuzin, in litt., May 1996; Aulagnier et al., in press). The remnant population in the Souss Valley has been extirpated (Cuzin, 1996). The total number in Morocco, from the Draa Valley northwards, is estimated at 500800 (F. Cuzin, in litt., May 1996). Southward through the Western Sahara, the distribution and abundance of the species has been considerably reduced, but several hundred are thought to remain, mostly in the Adrar Soutouf in the far south (F. Cuzin, in litt., May 1996; Aulagnier et al., in press). Poaching, habitat loss due to overgrazing and permanent agriculture are the primary threats to the species (Aulagnier et al., in press, Cuzin 2003).

\section{Algeria: Probably Vulnerable.}

With the possible exception of the dunes in the southwest (i.e., Erg Chech and Erg d'Iguidi), Dorcas gazelle historically occurred throughout Algeria (Lavauden, 1926; Dupuy, 1967; DeSmet, 1988; Kowalski and Rzebik-Kowalska, 1991). There is some question of the validity of 19th century reports of the species in the Mediterranean coastal area, because of possible confusion with Gazella cuvieri (Kowalski and RzebikKowalska, 1991), but given the species broad occurrence in coastal areas elsewhere in its range, it is likely that the reports are valid. The distribution of Gazella dorcas has gradually retracted southward throughout the 19th and 20th centuries. In the 1920s and 1930s, it remained widely distributed and common on the High Plateau from Morocco to Tunisia, on the plateaux south of the Saharan Atlas, between the Great Eastern and Great Western ergs, and throughout the southeastern portion of the country (Joleaud, 1929; Maydon, 1935). Its distribution and numbers declined through the mid-1900s, particularly during the 1960s and 1970s due to motorized hunting, but it remained common and locally abundant in many parts of its Algerian range into the 1970s and 1980s (Dupuy, 1966; Anon., 1987f). The northern limits of the species' range continued to move southward, however, and by the 1980s, it did no longer occurred north of the Saharan Atlas (Kowalski and Rzebik-Kowalska, 1991; De Smet and Mallon, in press). Dorcas gazelle presumably remains widely distributed in the Saharan zone of Algeria, but numbers are believed to greatly reduced (De Smet and Mallon, in press). Control of firearms due to military activity in recent years apparently has reduced poaching (De Smet, pers. comm., March 1997) but not enough to stop the decline of the species (De Smet and Mallon, in press). No estimate of numbers in the wild is available.

\section{Tunisia: Vulnerable.}

Dorcas gazelle formerly occurred throughout Tunisia, south and east of the Tell Atlas, and north and east of the Great Eastern Erg (Whitaker 1896; Lavauden, 1926b, Joleaud, 1929; De Smet, pers. comm., May 1996). In the early 1900s, the species remained well distributed in the country and was observed in large herds in areas such as the grassland plains bordering the Mehedra plateaux (Lavauden, 1926b, Schomber and Kock, 1961). At that time herds, of 50-80 were not uncommon, and occassionally concentrations of several hundred animals were seen. By the 1920s, however, the species reportedly was in decline. The northern limit of its range was moving southward, and large herds were uncommon (Lavauden, 1920, 1926). In the 1960s, Gazella dorcas had largely disappeared from the north. It still occurred north of Chott El Jerid to the Saharan Atlas (Müller, 1966), but it was markedly less numerous in the central than in southern districts, where moderate herds could still be found in sub-desert steppe east of the Great Eastern Erg (Schomber and Kock, 1961).

Dorcas gazelle is presently limited to the southern half of the country, approximately south of a line between Gafsa and Gabes (i.e., $34^{\circ}-35^{\circ} \mathrm{N}$ Latitude) (Smith et al., in press). Specific information on distribution and numbers of the species within this range is largely lacking. Illegal hunting and habitat degradation due to livestock overgrazing continue to be threats.

\section{Libya: Endangered.}

Limited information from Libya, coupled with reports of the species in bordering areas of Algeria (De Smet, 1988), Tunisia (Lavauden, 1926b), Niger (Grettenberger and Newby, 1990), Sudan (Hillman and Fryxell, 1990), and Egypt (Saleh, 1987), indicate that Gazella dorcas was historically distributed throughout the 
country (Hufnagl, 1972; Essghaier, 1980; Esschaier and Johnson, 1981; Anon., 1987; Khattabi and Mallon, in press). In the 1960s and 1970s, the species was still widely distributed across the northern and central regions (Essghaier, 1980), and in the southeast, and it remained abundant in a few areas, such as the Hammada El Hamra in the west and Djebil Uwenait in the southeast (Misonne, 1977; Essghaier, 1980). Overall, however, its numbers and distribution were declining rapidly at that time, due to uncontrolled motorised hunting (Hufnagl, 1972). In the late 1980s, the species still occurred locally in Libya but in greatly reduced numbers (East, 1992). The situation reportedly remains the same (Khattabi and Mallon, in press), however, information on the current distribution and numbers of the species is lacking.

\section{Egypt: Vulnerable.}

The historical range of Gazella dorcas included the northern, central, and eastern parts of Egypt (Saleh, 1987). With the exception of the vicinity of Djebil Uwenait and Gilf Kebir (Osborn and Krombein, 1969), there are no records of the species in the arid west-central and southwestern districts (Osborn and Helmy, 1980; Saleh, in press). Due to human pressure, primarily hunting and trapping, the distribution and abundance of the species declined considerably during the late 1800s and early 1900s, and by the 1920s, it had disappeared from entire districts (Flower, 1932). By the 1960s, Gazella dorcas had been eliminated from the immediate vicinity of the Mediterraen coast and semi-desert areas with good pasture; elsewhere herds were small and uncommon (Hoogstraal, 1964). In the late 1980s, Dorcas gazelle no longer occurred in the northcentral region of the country from the Suez Canal through the Nile delta and westwards to the Quattara Depression, where important populations historically occurred. It still occurred over most of the remainder (i.e., southern parts) of the country, but populations were widely scattered. The few concentrations that remained were limited to remote, inaccessible areas, and the species was considered in eminent danger of extinction (Saleh, 1987).

Recent information is that Dorcas gazelle populations continue to decline throughout Egypt, due to uncontrolled hunting; it is estimated that between 1000 and 2000 survive, mostly outside protected areas (Saleh, in press).

\section{Mauritania: Endangered.}

Trotignon (1975) concluded that Dorcas gazelle historically was abundant throughout Mauritania, with the exception of the desertic heart of the Majabat Al Koubra in the east, and the southern portion of the Sahel zone in the south. Given the occurrence of the species in northern Sengal (Sournia and Dupuy, 1990) and in Mali adjacent to the southeastern corner of Mauritania (Heringa, 1990), it is very likely that the historical range of Dorcas gazelle encompassed all of the country. The species experienced a catastrophic decline during the 1950s and 1960s. In areas where herds numbering in the dozens were once common, only isolated individuals were observed by the early 1970s (Trotignon, 1975). In the late 1970s, Lamarche (1980) reported that it was rare in the Majabat al Koubra. A population in the Banc d'Arguin National Park, which once numbered 200 (Anon., 1987f), declined from approximately 100 to less than 10 between 1970 and 1983 (Verschuren, 1985). In the early 1980s, Dorcas gazelle was considered threatened (Newby, 1981a), and by the late 1980s, it had been largely extirpated and survived only in small numbers in very remote areas (Sournia and Verschuren, 1990). More recently, a population of ca 40 individuals survived on Tidra, an island situated in southwest of Banc d'Arguin National Park (F. Lamarque, com. pers., 2005). Dorcas gazelle has recently been observed in the Maqteir in the northwest, and it probably still occurs in the Areg Chach and Hank Escarptment in the northeast (B. Lamarche and O. Hammerlynck, in litt., April 1997). Information on the status of the species elsewhere, e.g., in the continental part of Banc d'Arguin NP, is unavailable. Illegal hunting is a serious threat to this and other antelope species, and it largely occurs in inaccessible areas. (O. Hammerlynck, in litt., April 1997).

\section{Mali: Probably Endangered.}

Heringa's (1990) range map for Dorcas gazelle includes all of the Sahel and Sahara zones of Mali, i.e., everything north of about $150 \mathrm{~N}$ latitude, which probably represents the overall historical distribution of the species. It apparently never occurred, however, in most arid deserts in the north (Heringa, 1990). This is consistent with the lack of records for the species in adjoining, hyper-arid areas of Algeria (De Smet, 1988). However, records of Gazella leptoceros, a desert-loving species, also are lacking from northern Mali and southwestern Algeria, and the absence of records of Dorcas gazelle (and other antelopes) in this area (Sayer, 1977) may be related to its remoteness. Gazella dorcas was formerly locally common in Mali (Heringa, 1990). In the 1970s, it still occurred throughout the country, but it was rare and locally extirpated in much of the Sahel zone, and its numbers had been greatly reduced in the northeast (Adrar des Iforhas and Tilemsi) (Sayer, 1977). In the early 1980s, its distribution and overall abundance had been further reduced, but it remained locally abundant in a few areas, such as the vicinity of Gao (J.M. Pavy, in litt., September 1996). In the late 1980s, small populations also survived in the Elephant Faunal Reserve and the AnsongoManaka Faunal Reserve in the Sahel zone, at the southern extremity of the species' range (Heringa, 1990). Uncontrolled hunting and severe drought have severely impacted the Dorcas Gazelle population in northern Mali in recent years (East, 1997a). To the south in the sub-desert zone (northern Sahel), the species remains 
widely distributed in small populations that may total 2000 to 2500 animals (Niagate, 1996; J.M. Pavy, in litt., September 1996). Numbers apparently increased during the rebellion in early 1990s (Niagate, 1996). Information is lacking on the status of remnant populations in the Elephant and Ansongo-Manaka, but recent records of Dorcas are rare. Nowadays, the area with the highest density of

Dorcas Gazelle is the Northern part of the Tamesna plain, in the South-West of the Adrar des Iforas. However, Dorcas gazelles are heavily poached in that easily accessible area which make them particulary vulnerable (Lamarque et Niagaté, 2004). If present population estimates are reasonably accurate, the species undoubtedly is threatened.

\section{Niger: Probably Vulnerable or Endangered.}

The historical range of Gazella dorcas in Niger likely was not substantially different from that in the 1980s, when the species occurred throughout the country north of approximately the 14th parallel (Grettenberger, 1987; Grettenberger and Newby, 1990). Within this area, it apparently was absent from the high elevations of the Air Mountains and the interior of the Ténéré Desert to the northeast. In the early 1980s, it was estimated that 5000 or more survived within the Aïr Ténéré National Nature Reserve, and several thousands occurred in the Termit area to the southeast (Grettenberger and Newby, 1990). Historically the species probably numbered in the tens of thousands, or more. Recent estimates of 20000 country-wide (Dragesco-Joffe, 1993) and several thousand in the Aïr Ténéré National Nature Reserve (Poilecot, 1996) are based on data from 1991 or before, and the present status of the species is unknown. Illegal hunting, habitat degradation, and competition with livestock (Grettenberger and Newby, 1990) probably remain threats. The SSIG reconnaissance survey through ATNNR in Feb-Mar 2002 estimated a crude density of c. 0.25 dorcas seen $/ \mathrm{km} 2$ on the perimeter of the Air massif, well within the range of densities reported by Poilecot 10 years previously.

\section{Chad: Probably Vulnerable or Endangered.}

In the late 1970s, Dorcas gazelle occurred throughout Chad north of 13o 30' N latitude (Newby, 1981a), and this probably represents the species' historical distribution in the country. It reportedly does not occur on the high massifs (Thomassey and Newby, 1988), but elsewhere its former distribution probably was uniform. In the late 1970s, it was estimated that approximately 35000 to 40000 Dorcas gazelles occurred in the Wadi Rimé Wadi Achim Faunal Reserve, which encompasses possibly a quarter of the species distributional range in Chad (Newby, 1981a). Despite intensive hunting pressure, particularly during the civil war, Dorcas gazelle remained widely distributed in Chad through the 1980s, when it was estimated that the species numbered in the low tens of thousands (Thomassey and Newby, 1990). Information on the status of the species since the 1980s is lacking. During the 1990s, the Chadian Direction of National

Parks and Faunal Reserves reported that Dorcas Gazelle remains in the Wadi Rimé Wadi Achim Faunal Reserve but in greatly reduced numbers (East, 1996a), and this likely is indicative of the species' status elsewhere in the country. However, recent prospections in the reserve in 2001 showed that Dorcas gazelles are still abundant in Wadi Rime Wadi Achim Faunal Reserve, this reserve having the highest density for the species for the whole of the Sahel region (Encounter rate index: 4,3 Dorcas gazelles /km) (Wacher et al. 2001).

\section{Sudan: Probably Near Threatened or Vulnerable.}

Dorcas gazelle was formerly well distributed throughout the desert and sub-desert zones of central and northern Sudan, from Chad and Libya to the Red Sea (Hillman and Fryxell, 1988). The southern limits of its range were approximately $140 \mathrm{~N}$ latitude in the West and $+160 \mathrm{~N}$ latitude in the East. It was probably common and locally abundant throughout this range.

Gazella dorcas was once particularly abundant in the vicinity of the Nile, from Wadi Halfa at the Egyptian border southward through Dongola and the Bayuda Desert (Hassaballa and Nimir, 1991) and in the vicinity of Wadi Howar in Northern Darfur (Maydon, 1923). It was common in the Red Sea Hills (Maydon, 1935). Dorcas gazelle undoubtedly has declined considerably in recent decades due to uncontrolled hunting and degradation/loss of habitat due to livestock overgrazing and agricultural encroachment (Hillman and Fryxell, 1988; East, 1996). The effects of land degradatin have been compounded by drought. In the 1930s, Gazella dorcas remained well distributed throughout its historical range (Brockelhurst, 1931; Maydon, 1935), but by the 1970s, it had disappeared from most of the northwestern and northeastern parts of the country (Ghobrial, 1974). In the 1980s, it remained widely distributed but in ever-fragmented and greatly reduced populations (Newby, 1981a; Hillman and Fryxell, 1988). The species still occurs in the deserts of northern Sudan, and unconfirmed information from hunters is that numbers in the region are locally good, and recent surveys have indicated that the species is still common in the Red Sea Hills (I. Hashim in litt., November 1996, December 1996).

\section{Senegal: Extinction in the wild; Reintroduced in large fences within protected areas.}

Poulet's (1972) sighting of Dorcas gazelle in the Fete-Ole area $100 \mathrm{~km}$ east of St. Louis is the only record for the species in Senegal. Peul tribesmen in the Ferlo region apparently have no name for the species, and it is 
likely that it historically occurred in Senegal only as a vagrant (Dupuy, 1984). Newby (1981) considered it rare in the country. In 1972; the Senegalese National Park Service introduced 15 Dorcas gazelles within Djoudj National Park in the northwest of the Park (Dupuy, 1984). This captive herd grew to approximately 50 by the early 1980s (Dupuy, 1984) but experienced a serious decline during the late 1980s (Sournia and Dupuy, 1990). It reportedly still occurs, but numbers are not known (B. Clark, in litt., September 1996). Cette partie n'est pas dans le texte français!

\section{Burkina Faso: Probably Endangered.}

Gazella dorcas historically occurred in the Sahel zone of northern Burkina Faso, where it still survived in the late 1980s. It was considered endangered at the time, due to poaching and habitat lost, and largely confined to the Seno-Mango area at the northern extremity within the Sahel Partial Faunal Reserve, at the Mali border (Heringa et al., 1990). There was no mention of Dorcas gazelle in a recent update on antelopes in Burkina Faso (East, 1996a), and its status in the country is unreported. Given the present level of human activity in the Sahel region, illegal hunting and habitat degradation probably remain serious threats to the species.

Nigeria: Possibly Extinct.

Dorcas gazelle reportedly is a rare inhabitant of the small area of Sahel in northeastern Nigeria, in the vicinity of Lake Chad (Anadu and Green, 1990). In the late 1980s, its status in the area was unknown, but it very possibly was extinct, due to overhunting hunting and habitat encroachment by livestock (Anadu and Green, 1990).

Ethiopia: Lower Risk.

The historical range of Gazella dorcas included the arid lowlands (steppe, semi-desert, and desert) of northern and eastern Ethiopia from the extreme north of the Eritrea province through the Danakil plains and to the foothills of the Chercher Mountains (Anonymous, 1987f, Hillman, 1988; Yom-Tov et al., 1995; Kingdon, 1997). In the mid-1980s, its numbers were unknown, but presumably stable, and its conservation status was considered satisfactory (Hillman, 1988). Gazella dorcas was not observed in recent aerial and ground surveys in Yangudi NP, but a population of several thousand is estimated to occur in the adjacent MilleSerdo reserve and Danakil desert to the north (East, 1997b). No information is available on the status of the species in the northwest, but given estimated numbers and tribal stability in the Mille- Serdo/Danakil area, the species presently appears to be stable and not threatened. 


\section{Additional information on COP14 Prop. 12 for inclusion of Gazella leptoceros (slender-horned Gazelle) in Appendix I}

Gazella leptoceros (slender-horned gazelle) is broadly recognized as "a poorly known species, compared with the other gazelles" (CMS 2006). The impact of present threats to the species (poaching, hunting, habitat loss and degradation, international trade) is consequently hard to estimate. When considering the impact of international trade on Gazella leptoceros, CITES Resolution Conf.9.24 (Rev.Cop13) should be applied : "When considering proposals to amend Appendix I or II, the Parties shall, by virtue of the precautionary approach and in case of uncertainty either as regards the status of a species or the impact of trade on the conservation of a species, act in the best interest of the conservation of the species concerned and adopt measures that are proportionate to the anticipated risks to the species."

\section{Biological Information (CITES Resolution Conf. 9.24 (Rev.CoP13) Annex I)}

\section{International and national recognition of the precarious conservation status of the species}

Gazella leptoceros is listed as Endangered with a decreasing wild population since 1990 by the International Union for the Conservation of Nature (IUCN Red List 2006).

The species is listed in Appendix I of the Convention on the Conservation of Migratory Species of Wild Animals (CMS) which includes "migratory species which are endangered" (CMS, Article III).

A 2006 assessment of the conservation status of the species shows that it is endangered in Egypt and in Mali; probably endangered in Algeria, Tunisia and Libya; in low numbers in Niger; rare in Chad; accidental in Morocco (CMS 2006 reproduced in Annex I of this document).

Available population data:

\begin{tabular}{|l|l|}
\hline Total Population Estimate & Source \\
\hline $\begin{array}{l}\text { Fewer than 2,500 animals, with sub-populations } \\
\text { consisting of no more than 250 mature individuals }\end{array}$ & $\begin{array}{l}\text { CMS ScC13 2005 and Mallon } \\
\text { \& Kingswood 2001 }\end{array}$ \\
\hline $\begin{array}{l}\text { The global population may only number a few hundred } \\
\text { and the population is declining }\end{array}$ & East 1999 \\
\hline Up to 189 animals may be currently in captivity & Mallon\& Kingswood 2001 \\
\hline $\begin{array}{l}\text { The Tunisian population may number a few hundred } \\
\text { individuals, but more data are needed to verify this } \\
\text { preliminary assessment }\end{array}$ & CMS 2006 \\
\hline Possibly Extinct in Sudan & CMS 2002 \\
\hline
\end{tabular}

\section{Data on the decrease of habitat and population}

Population declines and fragmentation, and the degradation and destruction of habitat of Gazella Leptoceros, are well documented by experts. A 2005 CMS report confirmed the precarious conservation status of the species in the following terms:

"The slender-horned gazelle was formerly found from Algeria to Mauritania eastward to Egypt and Sudan as far as the Nile River. The slender-horned gazelle is widespread in the great sandy deserts (ergs) of the North Africa and the Sahel but details of its range in the region are poorly known and there are no accurate population estimates. It still probably can be found over most of the area of its original range from Algeria to Egypt but in much reduced numbers and in highly fragmented and isolated populations (Anon., 1998). Fewer than half are thought to occur in protected areas (Mallon and Kingswood, 2001a). The only animals now surviving in the wild are ones living in inaccessible desert locations or on Reserves (AZA Antelope TAG, 2003).

(...) The slender-horned gazelle was predicted in 2001 to decline by at least $20 \%$ in the following five years, mainly as a result of continued trophy hunting despite the fact that the species is legally protected 
throughout its North African range. Laws are not effectively enforced (Mallon and Kingswood, 2001b). The species only seems to remain in areas inaccessible to motorized poaching parties (East, 1999)."

(CMS ScC13 2005 - emphasis added)

Algeria reports in CITES CoP14 Prop.12 that Gazella leptoceros is threatened by habitat destruction and degradation which is a problem shared by other range States. The decrease of habitat and of the range of slender-horned gazelles is broadly recognized internationally. Data provided by CMS and reproduced in the Annex of this document show that there is a significant decline in the range of the species and in its numbers:

"Gazella leptoceros leptoceros has vanished from most of its range in the Egyptian Western Desert. In the 1980's, the species was considered extinct in 5 of its 6 known localities in the eastern part of the Western Desert and very rare in the last, the complex of the Wadi el Ruwayan and its extension, the Wadi Muweilih, where a small group of about 15 animals was surviving; this group was later exterminated (Saleh, 1987, 1997). In the western part of the desert, around the Quattara depression and the Siwa oasis, its status was uncertain (Saleh, 1987). The situation was not known, either, in Libya, where in the 1970's, Essghaier (1980) noted groups of 10 to 20 around Jaghbub.

For Gazella leptoceros loderi there is no objective indication of range contraction. There are however incontestable signs of decreasing numbers." (CMS 2006 reproduced in Annex)

Experts also report acute enforcement problems which render national conservation efforts ineffective:

"The slender-horned gazelle was predicted in 2001 to decline by at least 20\% in the following five years, mainly as a result of continued trophy hunting despite the fact that the species is legally protected throughout its North African range. Laws are not effectively enforced" (Mallon \& Kingswood, 2001 and CMS ScC13 2005)

"[In Egypt] The slender-horned gazelle is protected by law, but the law is not enforced" (Saleh 2001 reproduced in CMS ScC13 2005).

Gazella leptoceros also is easily confused with Gazella dorcas, a species heavily hunted in the region and sought after for its value in international trade. This causes increased pressure on the precarious status of the species:

"During the 1980s the species was considered rare but field surveys of the slender-horned gazelle were problematic since animals are easily confused with Gazella dorcas." (CMS ScC13 2005 in reference to the situation in Niger)"

The rarity of Gazella leptoceros has become an incentive for hunters who seek the species as a valued prize:

"Currently there are no animals known to be within protected areas of Egypt. Because of its rarity, the species is relentlessly sought by hunters" (Saleh 2001 reproduced in CMS ScC13 2005).

The intensity of the exploitation for Gazella leptoceros comes in conflict with the low reproduction rate of the species which only produces one litter of one or two offsprings per year in the winter (Khammar and CMS 2006)

The species consequently meets the following biological criteria for a listing in CITES Appendix I:

- CITES Resolution 9.24 (Rev. CoP13), Annex I criteria A i), ii), iv) and v) : the wild population is small and is characterized by "an observed, inferred or projected decline in the number of individuals or the area and quality of habitat"; each subpopulation is "very small"; the wild population encounters "large short-term fluctuations in population size" and a "high vulnerability to either intrinsic or extrinsic factors";

- $\quad$ CITES Resolution 9.24 (Rev. CoP13), Annex I criteria B i), ii), iii), and iv): The wild population has a restricted area of distribution and is characterized by "fragmentation or occurrence at very few locations"; "large fluctuations in the area of distribution or the number of subpopulations", "a high vulnerability to either intrinsic or extrinsic factors" and "an observed, inferred or projected decrease in (...) the area of distribution, the area of habitat, the number of individuals and the quality of habitat" 
- CITES Resolution 9.24(Rev. CoP13), Annex I Criteria C i) and ii): there is "A marked decline in the population size in the wild, which has been (...)observed as ongoing (...) inferred or projected on the basis of (...) a decrease in area of habitat; a decrease in quality of habitat; levels or patterns of exploitation; a high vulnerability to either intrinsic or extrinsic factors;"

\section{Trade information}

CITES Article II, and RC 9.24 (Rev. CoP13), state that Appendix I shall include all species threatened with extinction which are or may be affected by trade.

RC 9.24 (Rev. CoP13) specifies in Annex 5 that a species "is or may be affected by trade" if:

3) "it is known to be in trade (using the definition of 'trade' in Article I of the Convention), and that trade has or may have a detrimental impact on the status of the species; or"

4) "it is suspected to be in trade, or there is demonstrable potential international demand for the species, that may be detrimental to its survival in the wild."

Analysis of the UNEP-WCMC CITES Trade Database shows that from 2000 to 2005, 36 live specimens were traded and all were reported to be captive-bred.

The existence of a demand for trade in Gazella leptoceros parts and products is confirmed:

- CMS experts refer to it in a 2005 report: "The horns were once common in Algerian shops but the population has declined because of hunting." (CMS ScC13 2005)

- Reliable information indicates the use of horns for traditional masks and the sale of trophies/horns as decoration in North-African markets

- Horns of the Sahara gazelles are traditionally used for protection against "bad luck" by nomads and populations in the semi-desert and desert areas of Algeria

- The sale of stuffed specimens used as decoration occurs in markets such as the markets of the Ghardaïa and Biskra regions in Algeria.

Hunting is a major threat to the species and research shows that hunting of north-African gazelles is partially motivated by trade (Cuzin, 2003).

Despite the highly endangered status of the species, hunting of Gazella leptoceros continues to be explicitly advertised on the internet (Sudan Wildlife Safaris CO LTD <http://www.sudanwlsaf.com/index1.html> consulted on March 16, 2007).

The fact that hunting occurs in violation of national conservation laws implies that the impact of illegal trade on the species is almost impossible to evaluate. The existence of illegal hunting for this species and the fact that hunting prohibitions are not respected could indicate that a thriving international black market is in place and affects illegally hunted slender-horned gazelles.

An Appendix I listing of the species would encourage greater cooperation among Range States of the species, greater control of illegal trade and better implementation of protective national laws of range States by potential consumer countries of trophies and parts and products.

A 2006 report on wildlife trade in Somalia mentions that antelope meat is sold in local restaurants in the Middle East. This report also mentions that the United Arab Emirates are "one of the most important importing countries for antelopes" and that "the selling price for antelopes varies between 600 and 700 US\$, although the actual price is difficult to asses because intermediate brokers are involved in the wildlife business." (Amir 2006)

Experts also report problems with the enforcement of national laws, which make national conservation efforts inefficient. With regard to hunting infractions in Algeria, the information provided by the national services of police shows that 4 infractions were found in 2002 and 2004 in the wilayas of Tebessa, Béchar, El Oued and Ghardaia. These led to the arrest of 24 persons. These hunting infractions were:

- Death or harm inflicted on a protected animal

- Hunting, destruction, capture and sale of a protected animal 
Trade overview from 2000 to 2005 for Gazella leptoceros (slender-horned gazelles): (Range States of the species are marked with a $(*))$ :

Source: UNEP-WCMC CITES Trade Database, 2006.

\begin{tabular}{|l|l|l|l|l|l|l|}
\hline Term & $\mathbf{2 0 0 0}$ & $\mathbf{2 0 0 1}$ & $\mathbf{2 0 0 2}$ & $\mathbf{2 0 0 3}$ & $\mathbf{2 0 0 4}$ & $\mathbf{2 0 0 5}$ \\
\hline Live & 1 & 1 & 2 & 0 & 17 & 15 \\
\hline Purpose & Personal & Breeding & $\begin{array}{l}\text { Breeding/ } \\
\text { Zoos }\end{array}$ & NA & Scientific & Breeding \\
\hline Origin & Captivity & Captivity & Captivity & NA & $\begin{array}{l}\text { Born in } \\
\text { Captivity }\end{array}$ & Captivity \\
\hline Country of Export & Niger* & Belgium & Belgium & NA & $\begin{array}{l}\text { United } \\
\text { States }\end{array}$ & $\begin{array}{l}\text { United } \\
\text { States }\end{array}$ \\
\hline Country of Import & Saudi Arabia & Tunisia* & $\begin{array}{l}\text { Czech } \\
\text { Republic }\end{array}$ & NA & $\begin{array}{l}\text { United } \\
\text { Arab } \\
\text { Emirates }\end{array}$ & $\begin{array}{l}\text { United } \\
\text { Arab } \\
\text { Emirates }\end{array}$ \\
\hline
\end{tabular}

\section{Information on the consultation of Range States.}

Other range States for Gazella leptoceros are: Chad, Egypt, Libyan Arab Jamahiriya, Mali, Niger, Sudan (possibly extinct), Tunisia (IUCN 2006)

Consultations with representatives from other range States, and in particular with Arabic countries during a regional meeting in March 2007, were able to confirm the significant regression of this species and the degradation of its habitat. This species is thus confronted by high risks of trade in particular for trophies and decoration.

\section{References}

- Antelope Specialist Group 1996. Gazella leptoceros. In: IUCN 2006. 2006 IUCN Red List of Threatened Species. <www.iucnredlist.org>. Downloaded on 16 March 2007.

- CMS Technical Series Publication N ${ }^{\circ} 11$, Sahelo-Saharan Antelopes Status and Perspectives: Report on the conservation status of the six Sahelo-Saharan Antelopes, CMS SSA Concerted Action 2006 available online

- G. Amir, Wildlife Trade in Somalia, A report to the IUCN/SSC/Antelope Specialist Group - Northeast African Subgroup, 2006.

- Hadia Mostafa, Death of a Species, in Egypt Today - The Magazine of Egypt ; also published in Gnusletter Volume 23 Number 2, Jan. 2005; partly reproduced in African Indaba e-Newsletter Vol. 3 No. 2, March 2005 available online at < http://bigfivehq.com/no3-2.pdf>

- UNEP-WCMC, Review of CMS Concerted Action Species - CMS ScC13, 13th Scientific Council Meeting, Nairobi, Kenya, 16 - 18 November, 2005.

- CMS, Analysis of National Reports to the CMS 2005, Annex II: Appendix I Species, Prepared and produced by: UNEP World Conservation Monitoring Centre, Cambridge, UK on behalf of the Secretariat to the CMS available online.

- F. Cuzin, "Les Grands Mammifères du Maroc Méridonal (Haut Atlas, Anti Atlas et Sahara): Distribution, écologie et conservation", Phd research 2003.

- Second séminaire sur les antilopes Sahélo-Sahariennes, Rapports Nationaux, 2003 (includes information on Algeria, Burkina Faso, Ethiopia, Mali, Maroc, Mauritanie, Niger, Senegal, Sudan, Tchad, Tunisia)

- CMS, Synthesis of Party Reports, Part II: Information on Appendix I-listed Species, COP7 Conference Document: UNEP/CMS/Conf 7.6.1 Part II, Compiled by the UNEP - World Conservation Monitoring Centre under contract to the UNEP/CMS Secretariat September 2002 available online. 
- Mallon \& Kingswood. 2001.In Mallon, D. P. and Kingswood, S. C. (compilers). Antelopes. Part 4: North Africa, the Middle East, and Asia. Global survey and regional Action Plans. SSC Antelope Specialist Group, IUCN, Gland, Switzerland and Cambridge, UK.

- Saleh, M.A. (2001). Egypt. pp48-54. In: Mallon, D.P. and Kingswood, S.C. (comps.). Antelopes. Part 4: North Africa, the Middle East, and Asia. Global Survey and Regional Action Plans. SSC Antelope Specialist Group. IUCN, Gland, Switzerland and Cambridge, UK.

- $\quad$ East, R. (comp.) (1999). African Antelope Database 1998. Compiled by Rod East and the IUCN/SSC Antelope Specialist Group. Occasional paper of the IUCN Species Survival Commission No. 21. IUCN- The World Conservation Union 1999.

- Khammar, Programme pour l'Afrique du Nord; Projet Education et Conservation de la Biodiversité : La Gazelle ; available online at $<$ http://www.iucn.org/places/medoffice/nabp/web/documents/awareness/56.pdf> 


\section{ANNEX I: Information on Gazella leptoceros (Slender-Horned Gazelle) provided by the Convention on Migratory Species}

\section{Population estimates and distribution.}

Extract from CMS Technical Series Publication $N^{\circ} 11$, Sahelo-Saharan Antelopes Status and Perspectives: Report on the conservation status of the six Sahelo-Saharan Antelopes, CMS SSA Concerted Action 2006 available online.

\subsubsection{Decline of therange.}

Gazella leptoceros leptoceros has vanished from most of its range in the Egyptian Western Desert. In the 1980's, the species was considered extinct in 5 of its 6 known localities in the eastern part of the Western Desert and very rare in the last, the complex of the Wadi el Ruwayan and its extension, the Wadi Muweilih, where a small group of about 15 animals was surviving; this group was later exterminated (Saleh, 1987, 1997). In the western part of the desert, around the Quattara depression and the Siwa oasis, its status was uncertain (Saleh, 1987). The situation was not known, either, in Libya, where in the 1970's, Essghaier (1980) noted groups of 10 to 20 around Jaghbub.

For Gazella leptoceros loderi there is no objective indication of range contraction. There are however incontestable signs of decreasing numbers.

\subsubsection{Residential Distribution.}

G. I. leptoceros was eliminated from the biggest part of its range of distribution in the Egyptian Western Desert. In the 1980s, the species was considered extinct in five of its six known localities in the eastern part of the Western Desert and very rare in the sixth, the complex of the Wadi el Ruwayan and its extension, the Wadi Muweilih. In the western part of the desert, around the Quattara depression and the Siwa oasis, its status was uncertain (Saleh 1987). The small group of about 20 animals that was surviving in the Wadi el Ruwayan has been exterminated since then (Saleh 2001). Small groups (2-6) of Slender-Horned Gazelle were observed and photographed west of the Siwa oasis in 1998 (T.J.Wacher pers. comm.), but the situation has become uncertain since reports of more than 20 being killed by a single hunting party in that region in 2005. Small numbers may possibly persist in other parts of the the Quattara depression, the Jaghbub oasis, and the Kharga oasis (Devillers et al. 1999, 2006; Saleh 2001). It's current status in Libya is unclear.

There are relatively recent observations in most of the historical zones of distribution of Gazella leptoceros loderi. In Algeria, the species is distributed east of a line Saoura - Wadi Messaoud, in the Great Western Erg, the Great Eastern Erg, the Hamada de Tinrhert, and the smaller ergs around the central Saharan massifs of the Hoggar and the Tassili des Ajjers, in particular the Ahmer erg (Sclater \& Thomas, 1898; Trouessart, 1905; Lavauden, 1926; Joleaud, 1929; Dupuy, 1967; De Smet, 1989; Kowalski \& Rzebik-Kowalska, 1991; Dragesco-Joffé, 1993). In Tunisia, Gazella leptoceros loderi is present in unknown numbers, probably relatively low, in the Great Eastern Erg (Lavauden, 1920; Dragesco-Joffé, 1993; Kacem et al., 1994). In Libya, the distribution of central Saharan populations of Gazella leptoceros loderi includes the sandy zones of the Fezzan where there have been recent observations (Setzer, 1957; Hufnagl, 1972; Khattabi \& Mallon, 1997). The species probably still occurs in Mali. The range of populations of Gazella leptoceros loderi living in the ergs surrounding the massifs of the Hoggar and the Tassili indeed probably extends as far as Mali in the Tanezrouft (De Smet, 1989) and in the vicinity of the Adrar des Iforas (Pavy, 1996).

\subsubsection{Recolonisation prospects.}

Gazella leptoceros leptoceros

The habitats in most of the oases of the Lybian Desert of Egypt have been profoundly modified by agriculture and urbanization (Goodman et al., 1986). For a small species linked to the dunes and the peripheral acacia formations, it is probable that sufficient potentialities have survived around most of them (Saleh, 1987). Some of these have nevertheless been gravely affected by major infrastructure work (Saleh, 1987, 1997). The Siwa oasis is probably a particularly important site, for this species as for other antelopes. The two areas mentioned by Essghaier, the regions of Al Jaghub and Al Haruj al Aswad, should also be prospected.

\section{Gazella leptoceros loderi}

The erg habitat which Loder's Gazelle prefers is affected relatively little by the anthropic pressures that bear on most of the Sahelo-Saharan region, although Le Houérou (1986) and Karem et al. (1993) note the mutilation of ligneous species for firewood. The reoccupation of possibly lost range would thus not seem very difficult, especially since the species has a high rate of reproduction and exhibits migratory or erratic behaviour, two characteristics that suggert a reasonable colonisation potential. Locally, restoration of the vegetation cover might be necessary, and in all cases protection against human predation and excessive disturbance should be ensured. 


\subsection{Evolution and estimation of populations.}

At the beginning of the 1980's, Gazella leptoceros leptoceros was only surviving in small, widely dispersed groups, especially near uninhabited oases and in the Wadi El Rayan (Saleh, 1987). The numbers which seem to survive in the Egyptian northwest and perhaps in Kharga are certainly very low (Elbadry, 1998). It is probably the same for the possible remnant Libyan populations.

Population size of Gazella leptoceros loderi is very difficult to estimate. It seems clear, however, that it was much more abundant in the Algeria-Tunisia Great Ergs at the end of the 19th century and at the beginning of the 20th century than it has been in recent years. Large numbers were found, apparently relatively easily, by several naturalists of this period (Sclater \& Thomas, 1898; Lavauden, 1926; Heim de Balsac, 1928, 1936) whereas Le Houérou (1986) notes having seen only one throughout twenty-five years of prospecting for mapping the vegetation of North Africa.

Recent surveys in Tunisia (CMS, Jan-Feb and April-May 2006) confirm that the Slender-horned Gazelle is still present through the Tunisian part of the Great Oriental Erg from Djebil National Park to Senghar National Park, but that densities are probably very low. Evidence of poaching and disturbance is high. Observations suggest it is possible the Tunisian population may number a few hundred individuals, but more data are needed to verify this preliminary assessment (T.Wacher, pers.comm. 2006)

\subsection{Migration.}

Loder's gazelle and the slender-horned gazelle move frequently between desert depressions in search for food (Kacem et al., 1994; Saleh, 1997). Larger movements, likely to carry the species far from its preferred habitat, take place under the effect of long and severe droughts (Heim de Balsac, 1928).

These migrations have a cross-border character, at least between Algeria and Tunisia and between Egypt and Libya. It is also possible between Algeria and Mali, between Libya and Chad, and perhaps between Libya, Egypt or Chad and the Sudan.

\section{Conservation Status by Range State}

Extract from CMS Technical Series Publication $N^{\circ} 11$, Sahelo-Saharan Antelopes Status and Perspectives: Report on the conservation status of the six Sahelo-Saharan Antelopes, CMS SSA Concerted Action 2006 available online.

\section{Morocco : Accidental}

The only observation of Gazella leptoceros in Morocco is from the region of Boumia, southeast of the High Atlas, during the 1950's (Loggers et al., 1992). This record, situated outside the species' habitat, corresponds to the movements of large amplitude observed in years of great drought (Heim de Balsac, 1928).

\section{Algeria: Probably endangered}

The centre of gravity of the range of Gazella leptoceros loderi is in Algeria, east of a line Saoura - Wadi Messaoud, in the Grand Erg Occidental, the Grand Erg Oriental, the Hamada de Tinrhert, and the smaller ergs around the central Saharan massifs of the Hoggar and the Tassili des Ajjers, in particular the Ahmer erg (Sclater and Thomas, 1898; Trouessart, 1905; Lavauden, 1926; Joleaud, 1929; Dupuy, 1967; De Smet, 1989; Kowalski and Rzebik-Kowalska, 1991; Dragesco-Joffé, 1993).

\section{Tunisia: Probably endangered}

Loder's gazelle is present in unknown, probably relatively low, numbers in the Grand Erg Oriental (Lavauden, 1920; Dragesco-Joffé, 1993; Kacem et al., 1994).

\section{Libya: Probably endangered}

The distribution of central Saharan populations of Gazella leptoceros loderi includes the sandy zones of the Fezzan, where there have been recent observations (Setzer, 1957; Hufnagl, 1972; Khattabi and Mallon, 1997). Gazella leptoceros leptoceros is noted in the surroundings of the Jaghbub oasis, where small groups have been observed (Essghaier, 1980). Slender-horned gazelles noted more to the west in Libya, in particular, near Ajdabiyah in western Cyrenaica and near Dahra, north of Zella (Hufnagl, 1972; Essghaier, 1980), may also belong to the nominate form. 


\section{Egypt: Endangered}

The principal range of Gazella leptoceros leptoceros was situated in the northern part of the Egyptian Western Desert (Flower, 1932; Osborn and Helmy, 1980; Ayyud and Ghabbour, 1986; Le Houérou, 1986; Goodman et al., 1986; Saleh, 1987, 1997; Zahran and Willis, 1992). It is or was noted in Siwa in the northwest, in the Quattara Depression, Wadi Natroun and Wadi el Ruwayan near the lower Nile, in the Nile Valley, in dune systems between Faiyum and the Quattara Depression (Osborn and Helmy, 1980), in Bahariya (Saleh, 1987), and in Kharga (Elbadry, 1998). It seems to survive west of the Siwa oasis (Elbadry, 1998), perhaps also around the Quattara Depression (Salet, 1987, 1997; Elbadry, 1998) and the Kharga oasis (Elbadry, 1998). Gazella leptoceros loderi perhaps survives in small numbers in the extreme southwest of the country (Saleh, 1987, 1997; Elbadry, 1998).

\section{Mali: Status uncertain}

The population of Gazella leptoceros loderi living in the ergs surrounding the massifs of the Hoggar and the Tassili probably extend as far as Mali in the Tanezrouft (De Smet, 1989). The one mentionned in the vicinity of the Adrar des Iforas (Pavy, 1996) is now probably extinct (Lamarque, com. pers.).

\section{Niger: Probably endangered}

The species was noted in small numbers in the contact zone between the Airr and the Ténéré (Jones, 1973; Grettenberger and Newby, 1990; Poilecot, 1996b).

\section{Chad: Probably endangered}

The species seems rare in Chad where it is noted in two regions, the north of the Tibesti (Malbrant, 1952) and the region of the Erdi and the Mourdi depression in the Borku (Edmond-Blanc et al., 1962; Thomassey and Newby, 1990). There do not seem to be recent data in either of these regions. 